Nat. Hazards Earth Syst. Sci., 10, 605-622, 2010

www.nat-hazards-earth-syst-sci.net/10/605/2010/

(C) Author(s) 2010. This work is distributed under

the Creative Commons Attribution 3.0 License.

\title{
Earthquake hazard and damage on traditional rural structures in Turkey
}

\author{
H. H. Korkmaz ${ }^{1}$, S. Z. Korkmaz ${ }^{2}$, and M. S. Donduren ${ }^{1}$ \\ ${ }^{1}$ Selcuk University Eng. and Arch. Faculty Dept. of Civil Engineering, Konya, Turkey \\ ${ }^{2}$ Selcuk University Eng. and Arch. Faculty Dept. of Architecture, Konya, Turkey
}

Received: 27 February 2010 - Accepted: 19 March 2010 - Published: 31 March 2010

\begin{abstract}
During the last earthquakes in Turkey, reinforced concrete structures in the cities and masonry structures in the rural part were exposed to damage and failure. Masonry houses such as earthen, brick and stone structures are composed of building blocks with weak inter-binding action which have low tension capacity. Bending and shear forces generate tensile stresses which cannot be well tolerated. In this paper, the performance of masonry structures during recent earthquakes in Turkey is discussed with illustrative photographs taken after earthquakes. The followings are the main weakness in the materials and unreinforced masonry constructions and other reasons for the extensive damage of masonry buildings. Very low tensile and shear strength particularly with poor mortar, brittle behaviour in tension as well as compression, stress concentration at corners of windows and doors, overall unsymmetry in plan and elevation of building, unsymmetry due to imbalance in the sizes and positions of walls and openings in the walls, defects in construction such as use of substandard materials, unfilled joints between bricks, not-plump walls, improper bonding between walls at right angles etc.
\end{abstract}

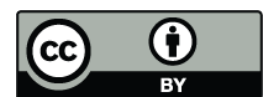

Correspondence to: M. S. Donduren (sdonduren@selcuk.edu.tr)

\section{Introduction}

Turkey is frequently exposed to destructive earthquakes with the shortest return period (Dogangun, 2004; Kaltakci et al., 2007; Arslan et al., 2007). During last earthquakes, reinforced concrete structures were heavily damaged and collapsed due to well known design, construction faults (Elnashai, 2000; Kaplan et al., 2005; Cagatay, 2005; Scawthorn and Johnson, 2000). Not only engineered structures, but also non-engineered traditional and rural structures failed causing loss of life and property (Adalier and Aydingun, 2001; Sezen et al., 2003). For example, 30000 died in Erzincan during the 1939 Richter Magnitude 8 earthquake where most of the collapsed buildings were unreinforced masonry (Bruneau, 2002). An earthquake of magnitude 6.0 occurred on 3 February 2002 causing damage and casualties at the city of Afyon and its provinces. The macroseismic epicenter is located near the Sultandagi provience. Total dead count is 42 with 325 injured. On 1 May 2003, an earthquake of magnitude 6.4 having its epicenter in the vicinity of Bingol occurred and 176 people lost their lives and 521 people were injured (Dogangun, 2004). A third earthquake with a Richter scale of 5.1 hit the Cat district of city Erzurum in 27 March 2004. Successive shocks continued until an outstanding tremor with an RS of 5.3 finally hit the Askale region in the following day. Since most people had been placed in the tents allocated by the Turkish Red Crescent in the first earthquake, no life losses noted in the second tremor contrary to the 9 dead witnessed in the former one. Afyon-Sultandagi Earthquake affected Aksehir and vicinity where common structure type is earthen (kerpic) or traditional Turkish types Himis or Baghdadi. Bingol and Erzurum Earthquakes were affected the regions where stone masonry structures are common.

Published by Copernicus Publications on behalf of the European Geosciences Union. 


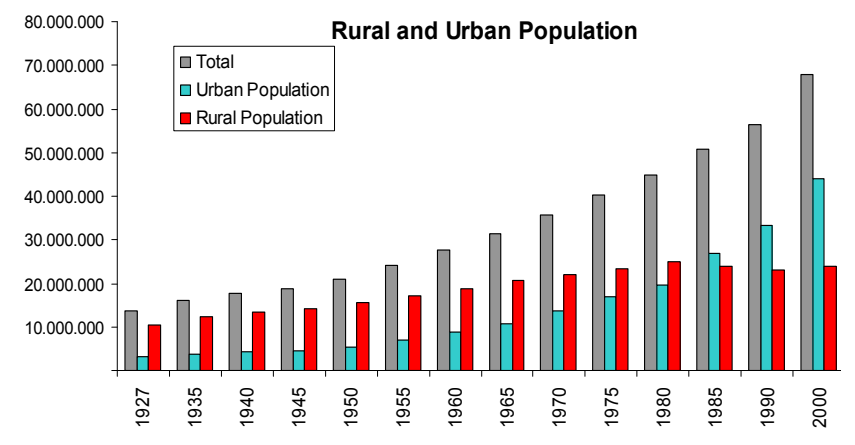

Fig. 1. Population tendencies of Turkey.

Not only Turkey, but also the neighbourhood countries, such as Iran, are under the risk of earthquake (Ahmadizadeh and Shakib, 2004). On 26 December 2003, a earthquake struck the south eastern of Iran (magnitude 6.6) killing more than 40000 , where the common structural type is adobe masonry (Hughes, 2000).

Common thing in those earthquakes is that; majority of the people dead or injured were living on rural or non-engineered masonry structures. On the other hand, generally, scientific researches are concentrated on seismic problems of reinforced concrete or steel structures. There are relatively less studies about the seismic problems of the rural or nonengineered structures. But it is a fact that there are also people living in non-engineered structures. Their problems are generally undervalued and paid insufficient attention to them.

In this study, classification of rural dwelling types in Turkey and their damage and failure characteristics during the last main earthquakes are summarized. The failure types are presented with the photographs taken in the affected are of Erzurum, Aksehir and Bingol. Since the data presented here can be beneficial for studies about strengthening of rural dwellings and earthquake mitigation studies, the classification and causes of failures are important.

\section{Earthquake as a crucial component in the natural niche of Turkey}

It is designated that $91 \%$ of the national territory and $98 \%$ of the overall population of Turkey are encompassed by the earthquake regions defined by governmental institutions. According to the Turkish State Institute Of Statistics (DIE) in 2009 , the overall population of the nation is 72562327 . Regarding the results of censuses conducted in 1995 and 2009, the population of the nation has risen $18 \%$ per five years. The ratio of the population increase goes up to $4 \%$ in rural regions. The populations of urban centers and rural districts in Turkey between 1927 and 2009 are illustrated in Fig. 1. The total number of residential and commercial buildings in Turkey and in some metropolitan areas in 2009 with respect to their structural materials is illustrated in Table 1 on the basis of Government Statistics Institute (DIE) statistics (www.die.gov.tr).

It can be comprehended that besides an excessive increase in urban population compared to the rural is clear. Recalling that $92 \%$ of the national territories encompassed by earthquake regions, this connotes that the number of people in the rural under seismic risk is boosted. Additionally, it should not be forgotten that vast majority of the people especially those immigrating the city from rural districts inhabits buildings constructed with their own efforts like shanties but not those erected with reinforced concrete or steel construction which necessitate engineering and architectural services. Referring to the public announcement made by Istanbul Metropolitan Municipality, it can be asserted that $60 \%$ of the residences in the city are unlicensed. People of low socioeconomic strata in cities tend to use some ruraloriginated construction techniques like adobe and stone masonry, himis and baghdadi (traditional Turkish rural structure types) that cost comparably low with regard to reinforced concrete buildings too. Consequently, not only in villages and counties, but also in cities, the number of people living in rural-originated structures, which lack engineering services, raises, which means an increase in the populace of people exposed to the danger of seismic threat and of those living in earthquake vulnerable structures.

Turkey, with more than $90 \%$ of its land being in highly seismic regions. During the last century, 111, 55 and 21 earthquakes took place with magnitudes greater than or equal to 5, 6 and 7, respectively. More than 80000 people died and about 500000 building collapsed or were heavily damaged (Cagatay, 2005). There are numerous studies in the literature about the earthquake hazards and corresponding post earthquake studies in Turkey (Catal, 1997; Arslan, 2006; Ulusay, 2004; Ulusay, 2005; Sancio, 2002; Bayraktar, 2004; Erdik, 2004; Binici, 2007; Guchan, 2007; Inel, 2008; Pamuk, 2005; Kaplan, 2007; Korkmaz, 2009).

\section{Rural residential structure types}

With the term "Rural Residence", it is implied the structures built by the dwellers themselves without any engineering services and with the use of local/regional material and technology. Not only in the rural regions, but also in the shanties located at the peripheries of the metropolises, most of the structures built are erected deprived of any engineering services such as architectural designing and static calculation stage. People maintain to use constructional techniques, which are formed by instinctively rather than technically, evolved with the earthquake experiences of former generations inherited to the succeeding ones making them defray its costs very hard. Since the minimization of the cost is inevitable in such structures, they are amassed either by dwellers or unqualified bricklayers. There may even be no foundation at all in 
Table 1. Approximate numbers of masonry buildings regarding their structural materials.

\begin{tabular}{lllllll}
\hline & Total & Briquette & Brick & Timber & Stone & Adobe \\
\hline Turkiye, Overall & 4001954 & 870841 & 1633219 & 174222 & 709094 & 546834 \\
Istanbul & 199223 & 50216 & 128503 & 8864 & 7526 & 1149 \\
Ankara & 251077 & 107598 & 93795 & 7778 & 12069 & 25699 \\
Izmir & 195482 & 24751 & 102383 & 4205 & 38673 & 22807 \\
Adana & 84577 & 48612 & 22990 & 3876 & 5060 & 2410 \\
Bingol & 10747 & 1310 & 4249 & 26 & 4706 & 122 \\
Kocaeli & 35759 & 7995 & 23482 & 1563 & 705 & 1389 \\
Afyon & 106175 & 2828 & 54257 & 9525 & 18956 & 19048 \\
Erzincan & 28694 & 2684 & 10104 & 1845 & 2752 & 6685 \\
\hline
\end{tabular}

some buildings, and those having may lack a well-arranged and rigid structure.

The fact that the rural residences are still being constructed with the use of similar materials and construction technology all over the world is a factor easing their classification. There are many very distinctive styles of traditional rural domestic architecture in Turkey, resulting from cultural attributes, related to material availability and climate. Rural houses are built by owners. Since the owner built one house during his life time, his building skills are not advanced. As a result of the different types of people constructing houses, it is not surprising to see that construction quality is variable (Hughes, 2000). In order to put forward these structures seismic behaviours, it is required that the existing structural types be known and classified in accordance with some specific criteria. The classification stated here is formed essentially regarding the structural system properties of rural structures. Structures are classified under 3 main headings namely the Masonry, Framework and Hybrid forms the lattermost of which is combinations of the former two types in some extents (Ersubasi, 2008).

\subsection{Masonry (Kargir) structures}

It is the structural practice leaning on the piling of various wall elements such as stones, adobe blocks, bricks, briquettes, and even timber in specific arrangements to form the structural system of a structure. Walls bear the vertical and horizontal loads acting on the structure (Korkmaz, 2007).

\subsubsection{Stone masonry structures}

In rural masonry structures, the filling materials of which are natural rocks and stones, two major groups of natural stones are used namely the random rubble debris stones and block stones. The type of stone filling used strongly affects the structural quality of the walls.

Random rubble stone debris is a group of stones, formed in river basins or at the skirts of hills with the toppling over of dislocated stones, which are mainly well rounded and hav- ing smooth surfaces which makes them also slippery. Debris stone masonry walls are laid down, making the larger stones placed at both sides of the wall forming a space in between. The remaining gap is filled with smaller stones and mud making the latter serves as a bonding material between the inner and outer walls. It is the most vulnerable masonry type regarding structural properties.

Block-stones can be identified as properly cut or dressed, considerably large units of stones. In block-stone masonry, larger blocks, supported by the smaller stone elements, form the exterior surfaces of the wall, whereas the interior surfaces are laid using smaller stone blocks. Mud, cement or lime mortar is used in the wall structure.

\subsubsection{Adobe masonry structures}

It is the mostly preferred structural practice in the regions where stone is not available geographically and climate is harshly arid. Being an effective isolator against hot and cold, adobe turns out to be the structural material of undeveloped regions where the provision of bricks and briquettes is quite troublesome. Clayey soil, water and straw are the ingredients of the adobe. The mortar formed by mixing these three basic components is filled into moulds and these moulds are left to dry on a plain ground (Fig. 2). The thickness of the wall varies 50 to $70 \mathrm{~cm}$. Mud is used as both the binding and plastering material. Adobe structures do have plain earth or timber roofing in general. The depth of the earth exceeds $50 \mathrm{~cm}$. Since the adobe blocks fabricated with earth and the mud mortar used as the binding material are made of the same materials, they amalgamate with time forming a continuous wall structure making it preferable to stone masonry. Nevertheless, the weakest side of adobe masonry is that it softens upon saturation and loses strength. To increase the bearing capacity of adobe masonry, which is low in general, timber girders (hatil) are used. Commonly, stone is used as the foundation material of adobe masonry structures. 


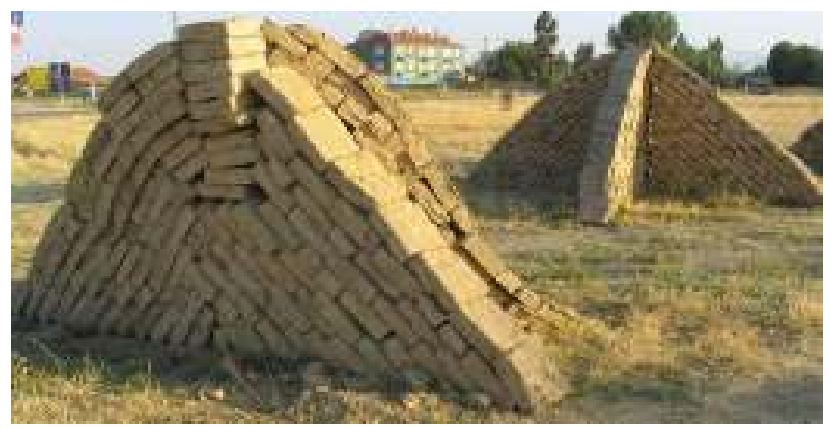

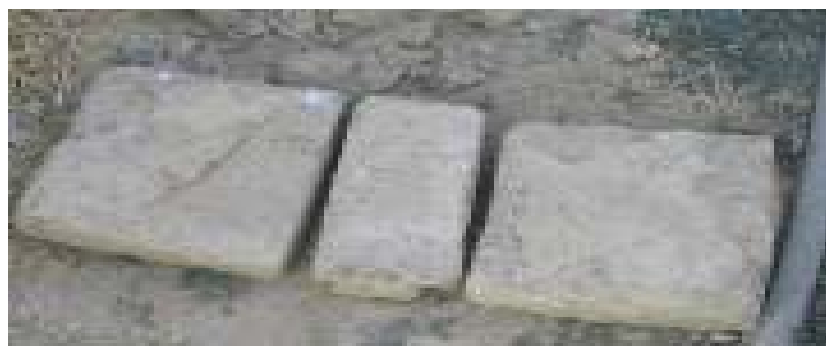

(a) Adobe production and blocks

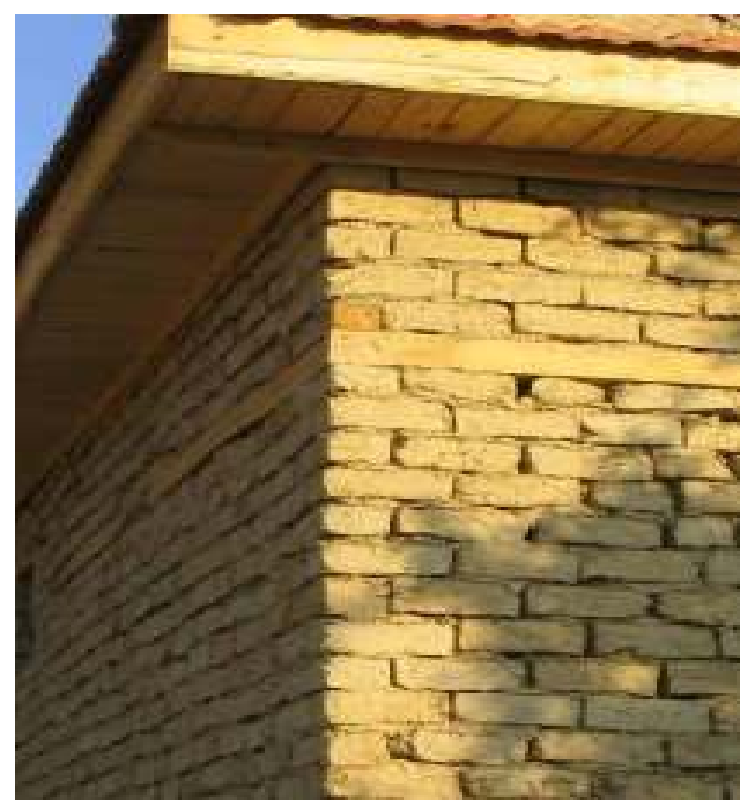

(b) Connection of corners

Fig. 2. Adobe construction (Source: H. H. Korkmaz).

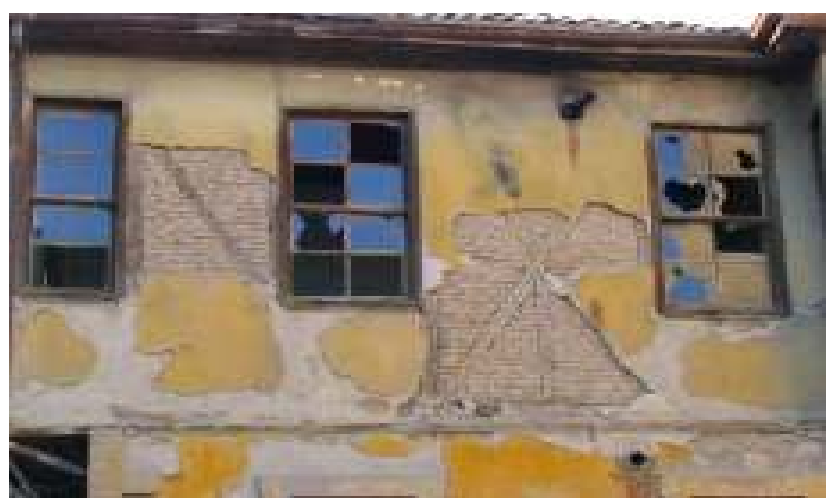

(a) Himis Structure

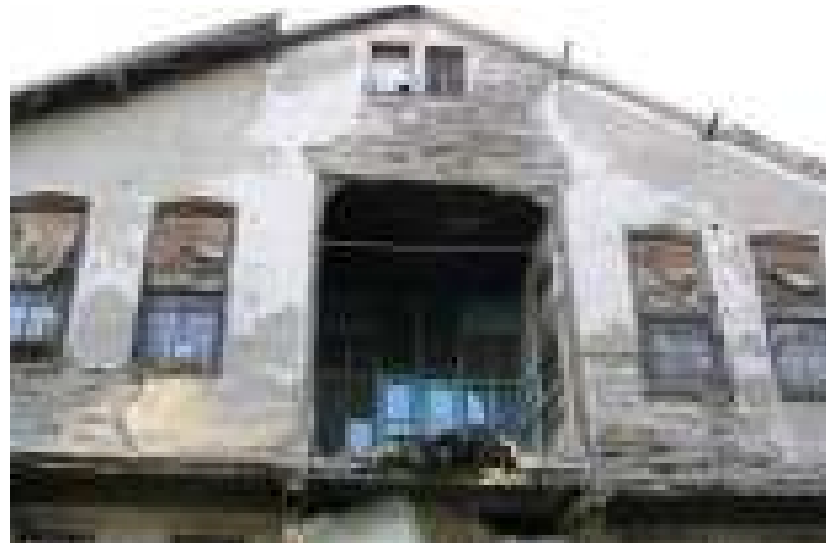

(b) Baghdadhi Structure

Fig. 3. Himis Structure and Baghdadhi Structure (Source: H. H. Korkmaz).

\subsubsection{Brick masonry, briquette masonry walls}

Bricks are unnatural structural "stones" manufactured in moulds from vacuumed clayey soil mud and heated under high temperatures upon demounting. In masonry wall construction, solid bricks, which are also named as firebricks (Harman-Bricks) and have no or little cavity inside, are used. Cement mortar is used to bind the adjacent bricks while laying the wall. While the foundation walls is approximately $50 \mathrm{~cm}$ that of brick walls located on the foundation walls remains at 20 to $30 \mathrm{~cm}$. Whereas $20 \mathrm{~cm}$ wall thickness seems sufficient for single-storey brick masonry buildings, a wall thickness of $30 \mathrm{~cm}$ is preferred at the ground floor of multi- storey buildings, keeping the wall thickness of higher storeys at $20 \mathrm{~cm}$. Beside the application of tiling on timber beams, earth amassing is also a common practice for roofing. Besides timber, reinforced concrete can also be seen in the floor and roof slabs.

Structures bearing the loads they are exposed to and transmitting these loads to its foundation by means of a framework are named as Framework-Structures. Frameworks utilized in rural structures are of timber or reinforced concrete. Those standing on timber framework are classified under two headings, namely himis and Baghdadi. 


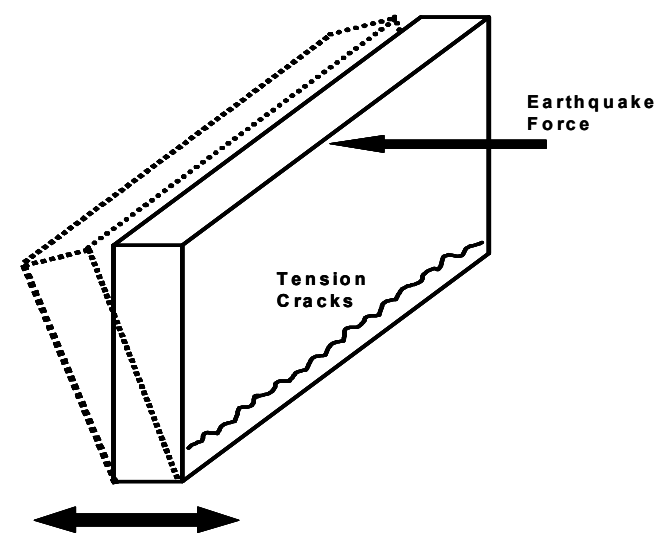

(a) Tension cracking under out-of-plane forces

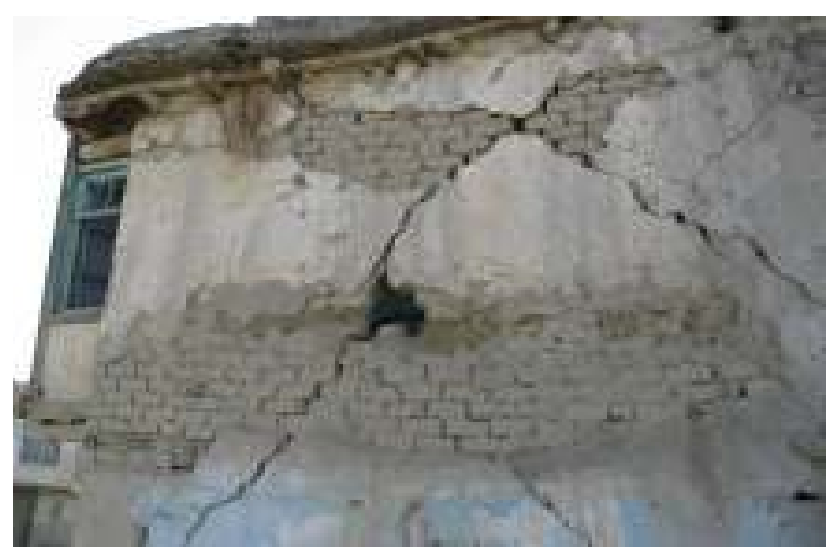

(c) Diagonal shear cracking (Source: H. H. Korkmaz)

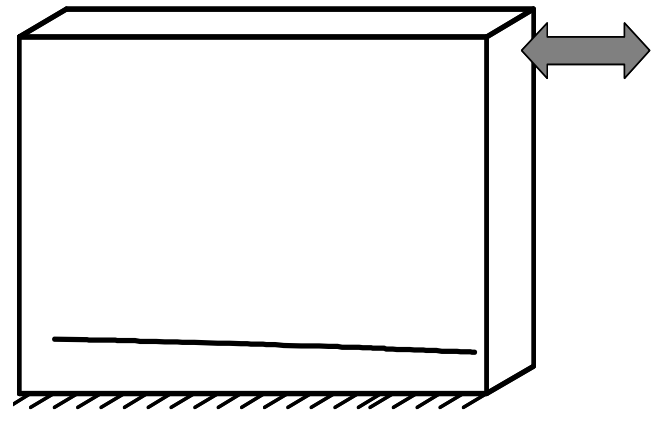

(b) Shear crack at the base

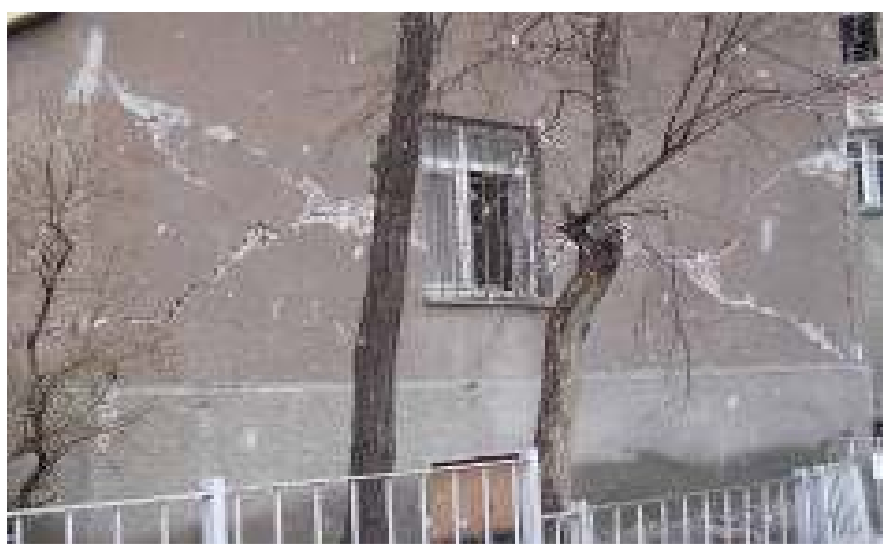

(d) Stepped shear cracking (Source: A. Turer)

Fig. 4. Cracks on a wall under earthquake forces.

\subsubsection{Himis structures}

In civil architecture, it is the structural type advanced on mastery use of genuine material. Before the amassing of the walls, a timber framework is erected by placing timber beams of various length and diameter vertically and diagonally. The structural openings are filled with a filling material abundant/easily accessible in the district like brick, stone or adobe (Fig. 3a). Mud is used as the binding and plastering material. Earthquake resistance capacity of this type may be medium or poor relying on the construction quality. Roofs are formed by placing tiles or accumulating earth on the roof trusses horizontally mounted.

\subsection{Structures with framework (karkas)}

\subsubsection{Baghdadi structures}

It is a more complicated and developed structural practice compared with himish. With the appropriate positioning of carpentry beams in vertical, diagonal and horizontal directions, the framework is erected. In between the wide and regularly formed timber strips screwed intermittently between the timber columns, viscous mud is poured and the exterior and interior surfaces of the wall is finished with the same mud. The structure of a typical Baghdadi wall is illustrated in Fig. 3b. The lightness of the walls with the strength of timber connections makes Baghdadi structures demonstrate a well performance under seismic loads.

\subsubsection{Hybrid structures}

Two-storey buildings, the first floor of which is amassed with masonry in general while reinforced concrete framework is being erected on the top floor, are called Hybrid Structures. Hybrid structures are composed of combinations of stone or brick masonry at the first floor and a framework system such as himis or baghdadi at the second floor.

\section{Earthquake damage on traditional rural structures}

Earthquake forces consist of a set of compressional and shear waves, shaking and moving the ground surface in three perpendicular directions in random fashion (Weldelibanos, 1993) and inertia forces are created throughout the mass of 


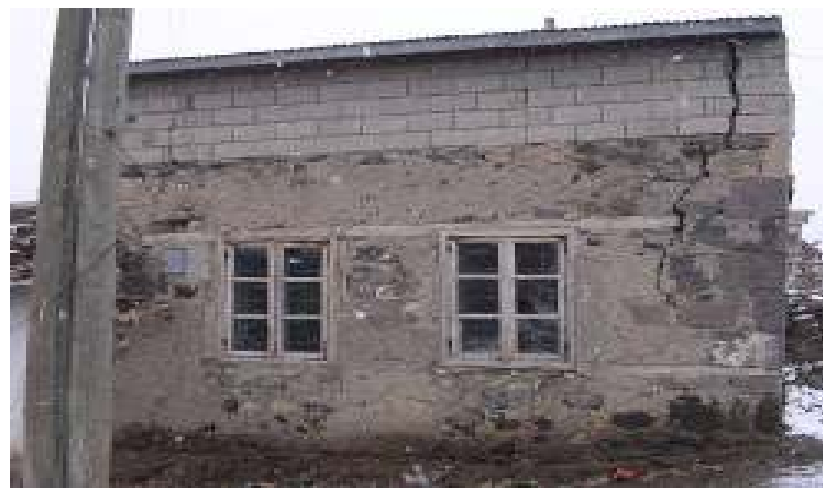

(a) Stone structure (Erzurum-2004) (Source: A. Turer)

Fig. 5. Vertical cracks near support edges of out-of-plane walls.

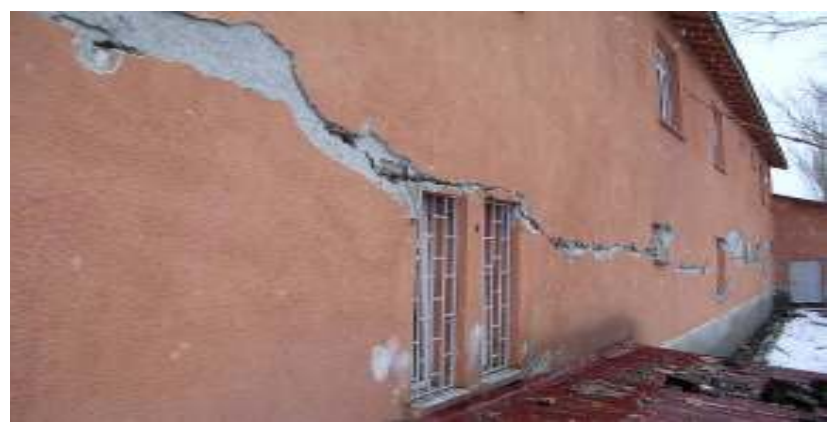

Fig. 6. Cracking of masonry wall with many openings (Erzurum, 2004) (Source: A. Turer).

the building and its contents. The structural elements such as walls, which normally bear only vertical loads, have to carry horizontal bending and shearing effects as well during an earthquake. When the bending tension due to earthquake exceeds the vertical compression, net tensile stress occurs. If the building material is weak in tension, such as brick or stone masonry, cracking occurs which reduces the effective area for resisting bending moment. It follows that the strength of material in tension and shear is important for earthquake resistance (Shaw and Okazaki, 2003).

In masonry structures, while the building is undamaged it will perform elastically, but as cracks develop, the dynamic vibration characteristics undergo significant changes. The fundamental vibration frequency decreases and the displacements increase by 2 or 3 orders of magnitude. When the cracks fully develop, each wall becomes an assemblage of broken adobe blocks rather than a monolithic element, and this condition can lead to the failure of the structure (Ginell and Tolles, 2000).

Of the great number of rural buildings subjected to past strong, rural masonry buildings were severely damaged, same collapsed not only because of their small or no ten-

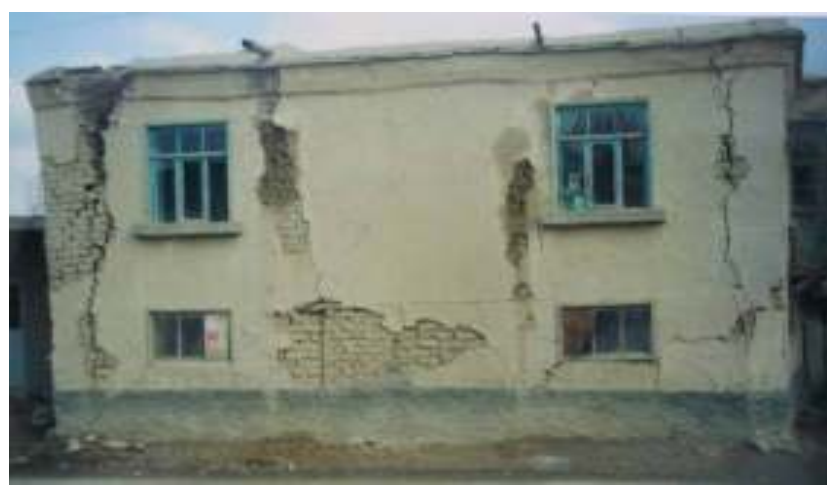

(b) Kerpic structure (Aksehir, 2003)

(Source: H. H. Korkmaz, S. Z. Korkmaz, M. S. Donduren)

sile strength, but also due to their heavy weight, lack of proper bonding between longitudinal and cross walls and poor workmanship.

In order to understand the behaviour of a masonry structure under earthquake effects, behaviour of a single free wall must be studied. If the earthquake forces act on a wall perpendicular to the wall plane, it tends to overturn it. The resistance of the wall is provided by the weight of the wall and the tensile strength of the wall material, which is very low. At the premature stage of the failure, tension cracks on the bottom of the wall (Fig. 4a) are propagated. At the failure stage, the wall overturns out of its plane.

When the earthquake forces are directed parallel to the wall plane, the resistance of the wall would be much higher. Due to their orientation, these walls provide the lateral load resistance of the building and undergo in-plane deformation and stresses. The resulting form of damage is a function of axial compressive load level, wall aspect ratio and quality of the mortar in components that compromise the wall. Depending on these factors, in-plane damage may take the form of diagonal, stair stepped, and horizontal flexural cracks. If the length-to-width ratio of the wall is small, sliding or shear cracks are formed (Fig. 4b). In the case of walls with moderate length-to-width ratio and strong mortar combinations, diagonal tension crack is formed (Fig. 4c). This crack becomes $X$ type when the earthquake is reversed. For low axial load and weak mortar combinations masonry units slide horizontally on each other forming a stair-stepped diagonal crack along the joints (Erbay, 2004). Diagonal cracks are turned to stepped type diagonal crack with a horizontal shear crack in the middle for the walls with large length-to-width ratio (Fig. 4d).

When a box like structure is subjected to an earthquake force, walls parallel to the earthquake motion behave as shear wall. The other two perpendicular walls vibrate due to inertia force acting normally to their planes (behave like a slab), generating bending moments where the maximum occurs at 

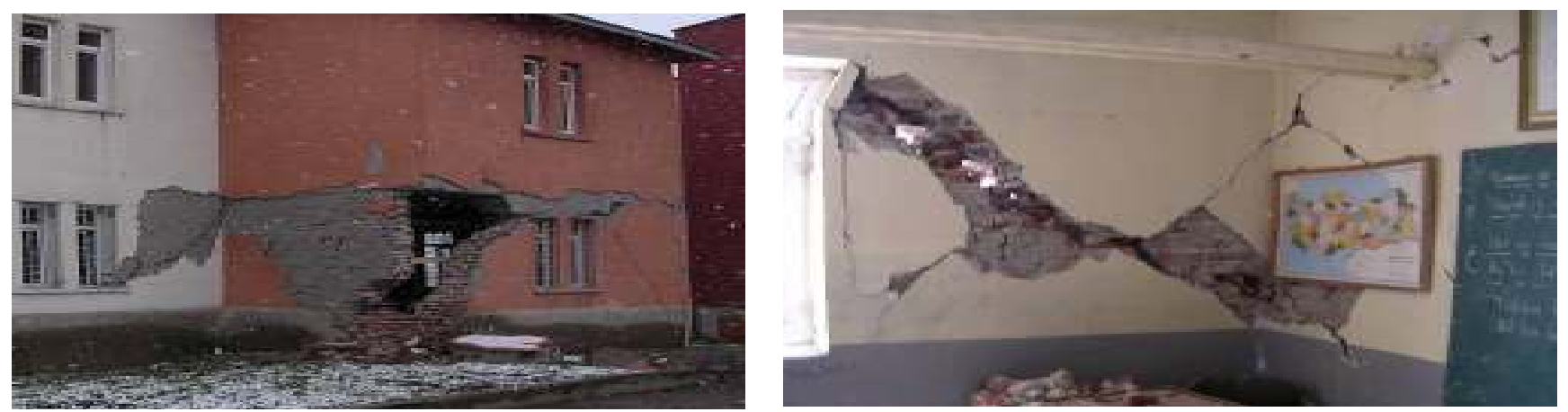

(a) Brick structure (Erzurum, 2004) (Source: A. Turer)
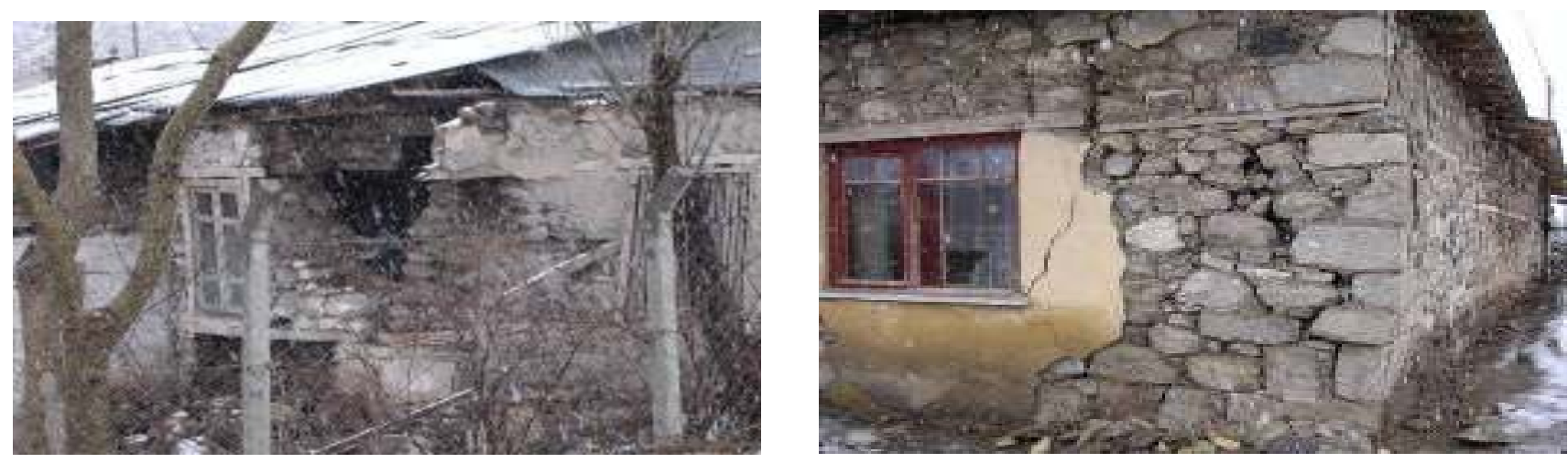

(b) Stone structure (Erzurum, 2004) (Source: A. Turer)

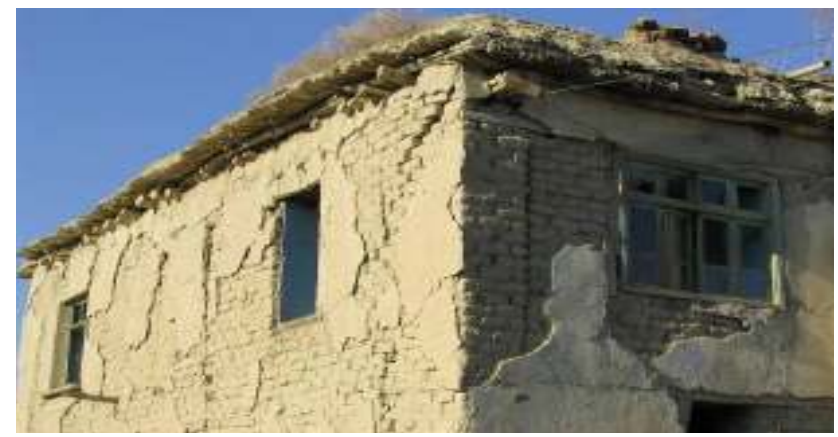

(c) Kerpic structure (Aksehir, 2003) (Source: H. H. Korkmaz, S. Z. Korkmaz, M. S. Donduren)

Fig. 7. Corner failure of masonry structures.
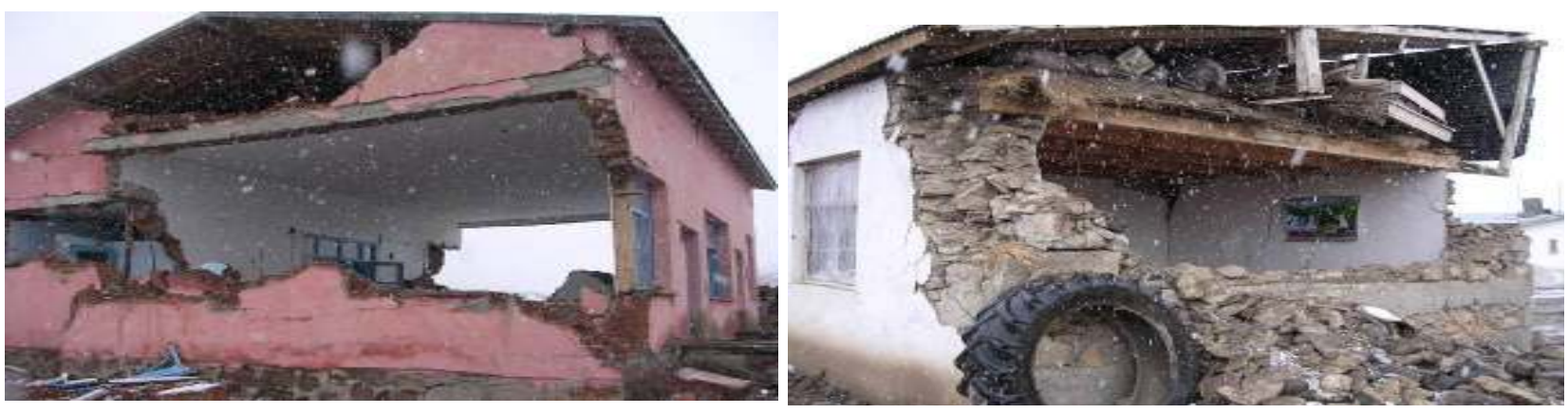

Fig. 8. Out-of-plane failure of masonry walls (Erzurum-2004) (Source: A. Turer). 


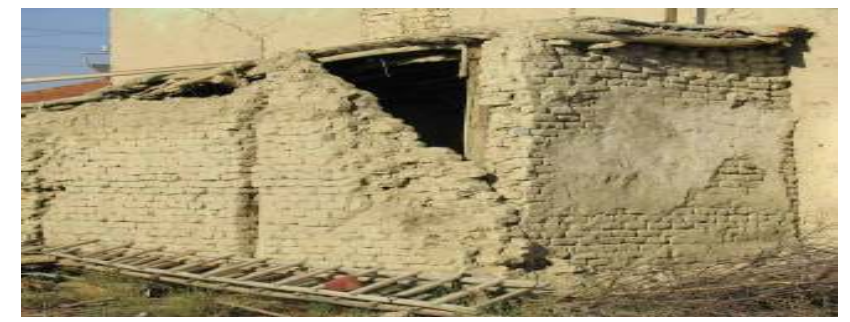

Fig. 9. Inadequate (no) connection between two intersecting walls and damage (Source: H. H. Korkmaz).

their lateral ends. If the roof of the structure is flexible, as it is the case for most "kerpic" structures in Turkey, formed by parallel beams that are not braced together, then the roof cannot act as a rigid diaphragm and it is unable to restrain the upper edge of the walls against movements perpendicular to their plan. Out of plane walls behave like free standing wall, vertical cracks formed along the support edges, that initiate near the roof and propagate downwards (Fig. 5), and the walls starts vibrating as a cantilever.

If the roof of the structure is rigid enough to act as diaphragm, if the roof is braced in its plane and has good connection with the walls, the structure will act as box-like system. In this case, resistance of the system is higher than the one with flexible roof. If there are enough walls in two orthogonal directions lateral strength can be rather high and therefore high seismic intensities can be withstood. In such buildings failure is characterized by diagonal cracks due to shear, and resistance can be drastically reduced if large openings or door and windows exist (Weldelibanos, 1993). If there exist more than one opening, the shortest path through the openings is the potential cracking track (Fig. 6). It can be easily said that, openings reduces the load carrying capacity of the walls.

The corner connection of the walls experiences higher stresses during earthquake action. At ground motion, all the structure is set in motion and different parts of the structure attempt to vibrate with different characteristics. The stiff structural system of the load-bearing walls and roof and the flexible characteristics of the non-load-bearing walls vibrate in perpendicular directions and the corners of the walls, being the junction between them are the areas of highest stress (Coburn, 1986). The behaviour of masonry buildings, as a whole, when

subjected to earthquakes are strongly dependent on how the walls are interconnected at the top levels. Corner separations are the most observed type of failures after earthquakes (Fig. 7). Once the corners have failed, the adjacent walls are more likely to fail out-of-plane and overturn (Fig. 8). Also, as the length of the walls increases, the out-of-plane and inplane resistance of walls decreases.

If there are no connection between two intersecting wall at the corner, separation of walls is inevitable (Fig. 9). If there exist opening in the wall such as door or windows, the wall portion between openings are become more flexible. The sections at the level of the top and bottom of opening are found to be the worst stresses in tension as well as in compression and those near the mid-height of piers carry the maximum shears. Under reversed direction of horizontal loading the sections carrying tensile and compressive stresses are also reversed. Thus it is seen that tension occurs in the jambs of openings and at the corners of the walls. The pier may fail either in shear due to diagonal tension or in flexure due to the vertical compression at the compressed corners (Fig. 10).

Size, number and location of openings also greatly influence the resistance of a building. Excessive wall openings, leaving insufficient wall areas to resist lateral shear, leading to shear (diagonal tension) failures (Yarar, 1985) while a wall with small and few openings suffer less damage during an earthquake. Openings too close to the corners also decrease the earthquake resistance (Patel and Pindoria, 2001).

Usually houses with two or three stories receive much more damage than hose with one story (Fig. 11). The geometry of a house in plan as well as in elevation has a significant effect on the distribution of the seismic forces. If there are no sudden changes, in stiffness and walls are uniformly distributed in both orthogonal directions then the behaviour of masonry building may be expected to be better. Unsymmetrical houses develop additional shearing forces due to twisting and warping. Irregular distribution of walls in plan can result in torsional effects and over stressing the wall in critical zones. Building with load bearing walls in one direction only represent an example of bad structural layout. Also peripheral walls with many openings, can not resist earthquake forces (Fig. 12).

In some cases dwellings are constructed adjacent to each other. This crates hammering effect during earthquake (Fig. 13a). Sometimes, for a new building adjacent to the other older building, only 3 walls are constructed and common wall of the older building is used for other side (Fig. 13b, see also Fig. 9). In this case, a box type structure can not be formed and failure is unavoidable. In Fig. 13c the neighbouring structure was failed and only common wall of the older building is seen.

In Turkey, it is very common to use round wooden logs (unshaped) as roof beams. Those beams are placed on two parallel walls. As a result other two walls become unrestrained at the top (roof level). The damage is likely to occur for those unrestrained walls. The probable failure mode is out-of-plane collapse of the walls (Fig. 14). Also in Fig. 14b, it is seen that, the round beam member is rolled and failed in the living space of the structure. Another factor leading to failure of roof beams is that they are not fully rest on the top of the walls. Only a small portion of the beams are rest on the walls. Beams must be extended, at least, $50 \mathrm{~cm}$ beyond the walls towards outside. 

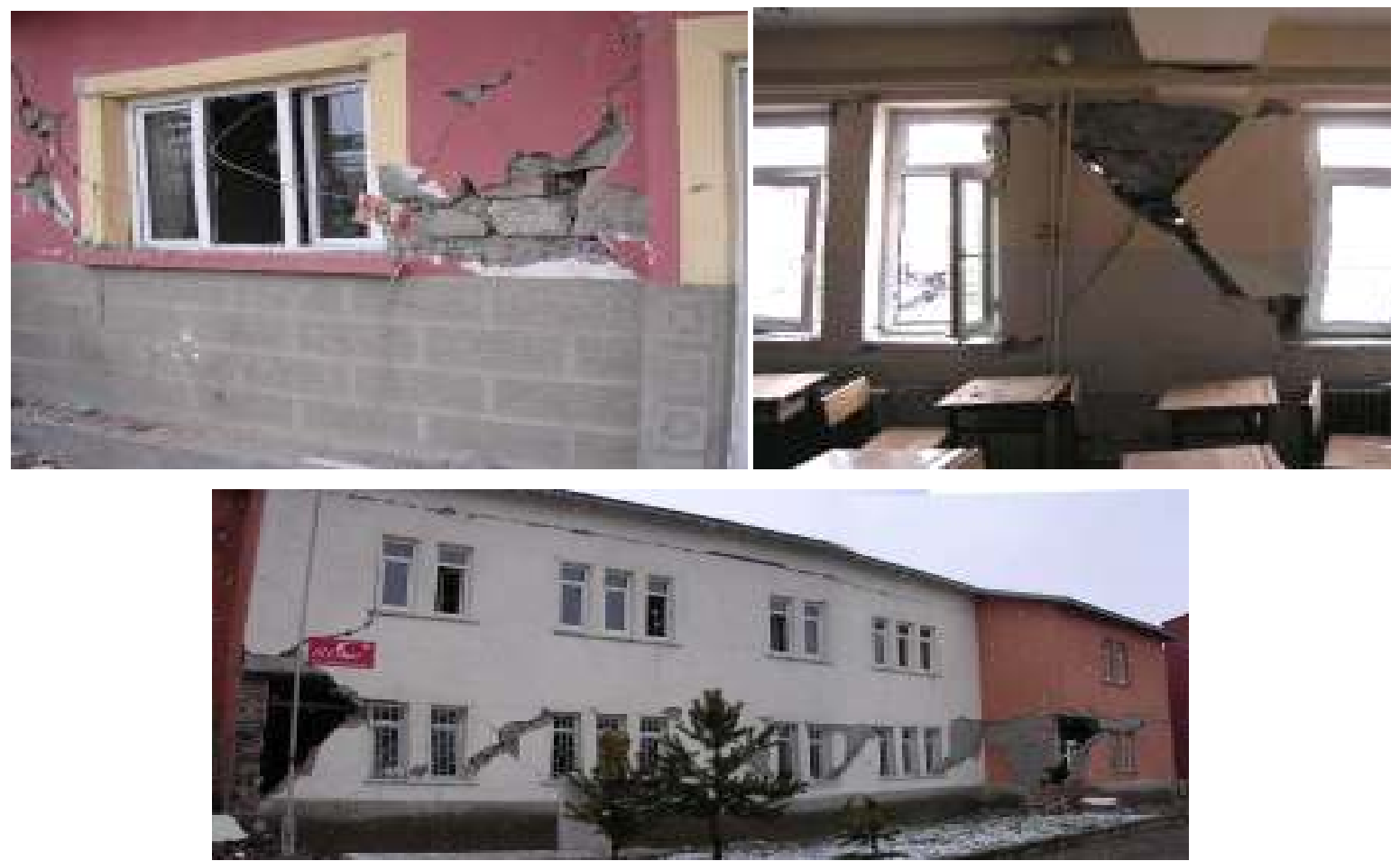

Fig. 10. Shear cracks of piers between windows (Erzurum, 2004) (Source: A. Turer).
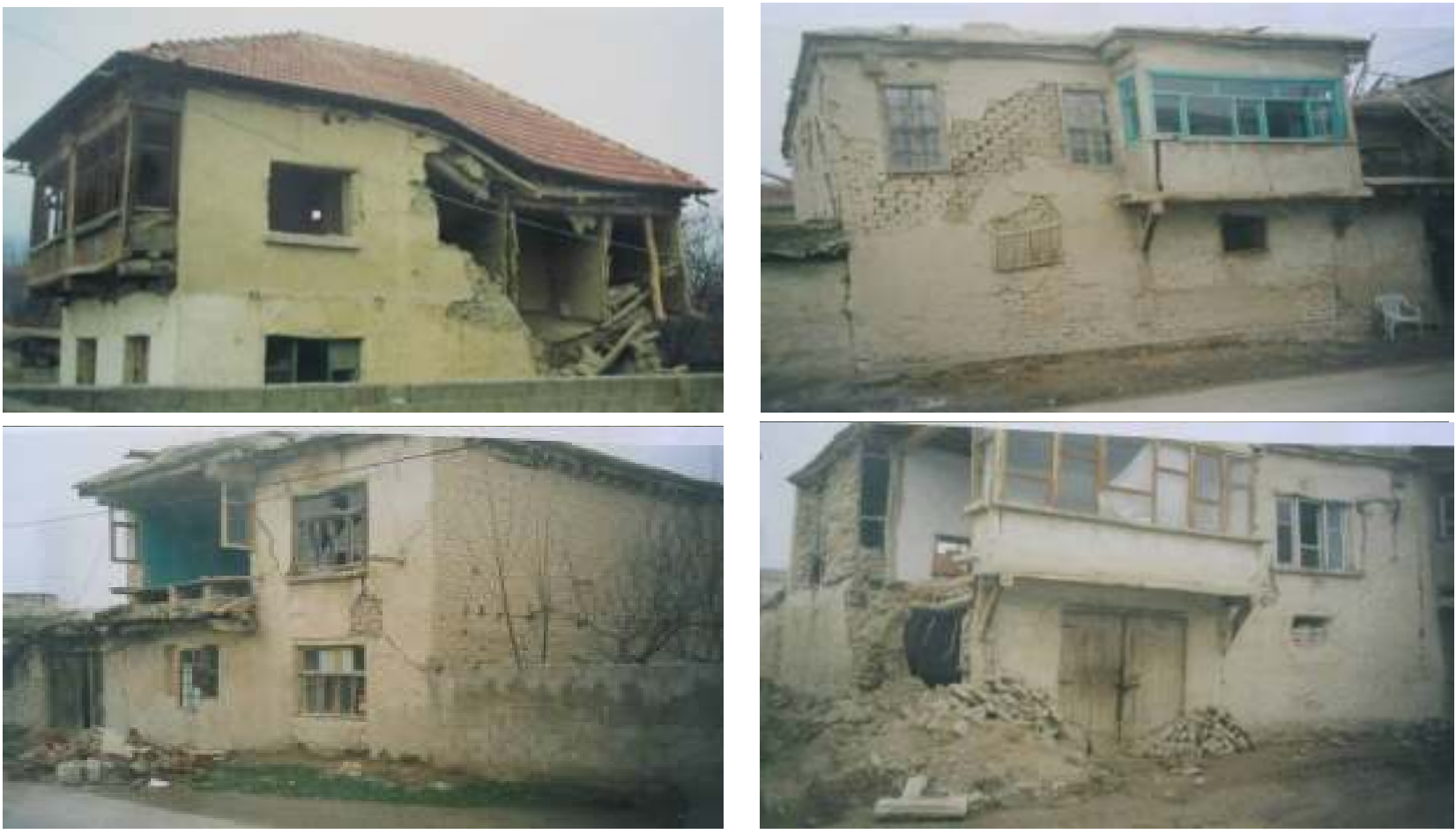

Fig. 11. Damage of multistory houses (Source: D. Aydin). 

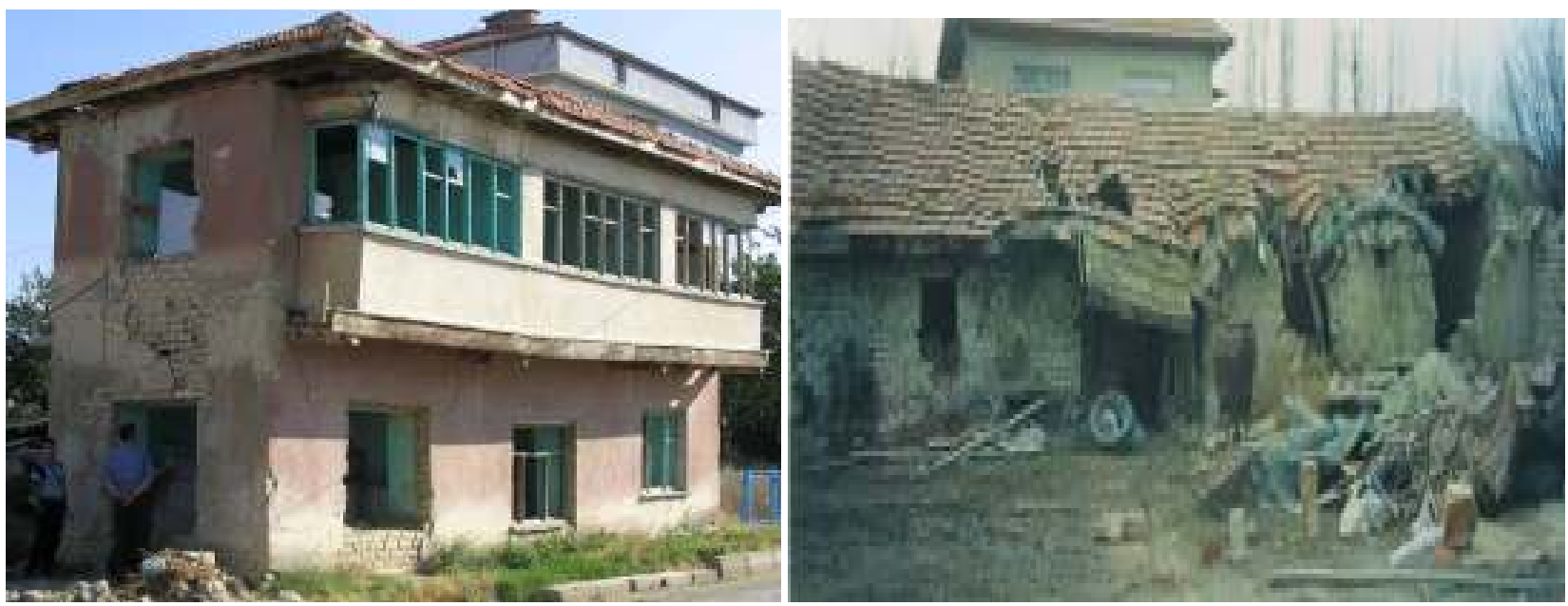

Fig. 12. Failure of structures with bad geometry (Aksehir, 2003) (Source: H. H. Korkmaz, S. Z. Korkmaz, M. S. Donduren).

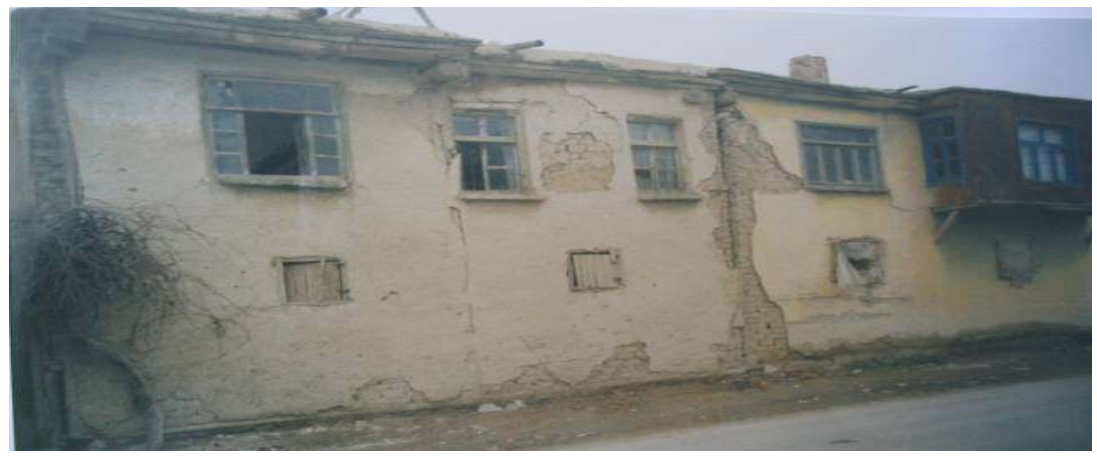

(a) Cases dwellings are constructed adjacent to each other (Source: H. H. Korkmaz, S. Z. Korkmaz, M. S. Donduren)

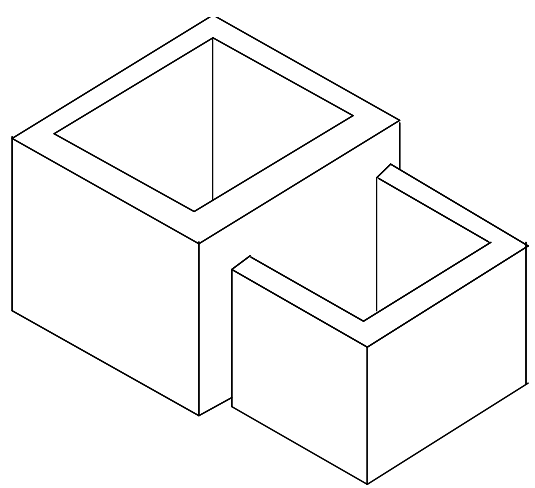

(b) Other side

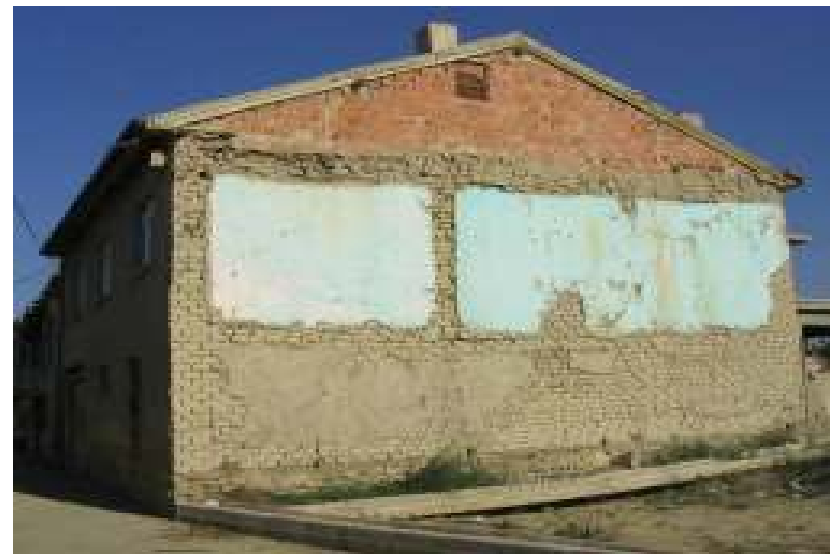

(c) Neighbouring structure

(Source: H. H. Korkmaz, S. Z. Korkmaz, M. S. Donduren)

Fig. 13. Problems of adjacent buildings (Aksehir, 2003). 


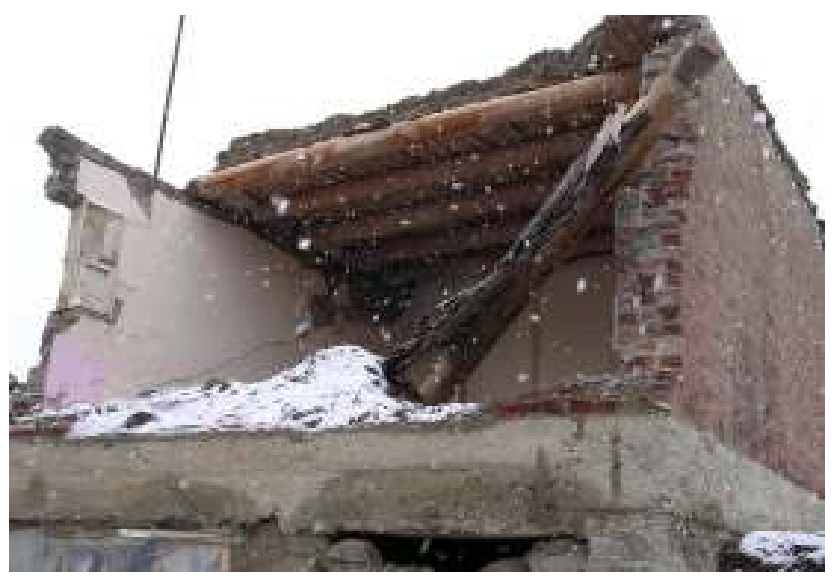

(a) Out-of-plane collapse of the walls (Source: A. Turer)

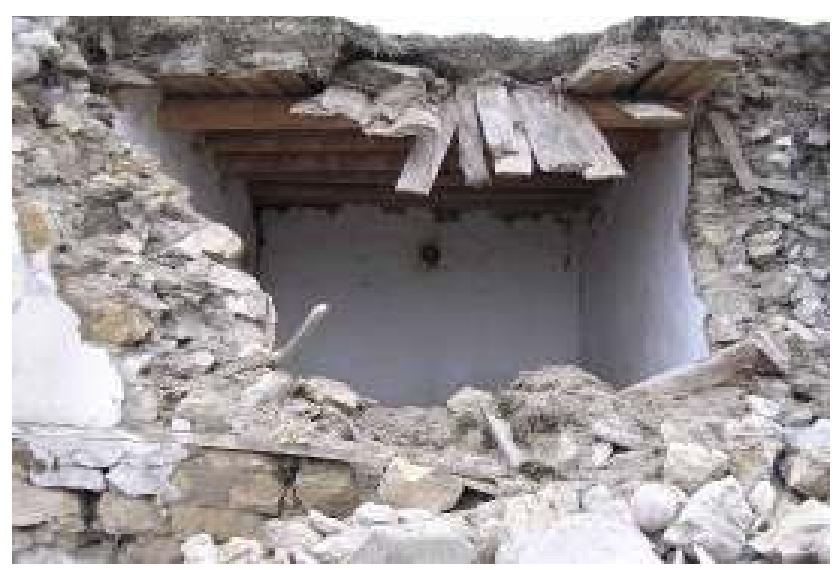

(b) The round beam member is rolled (Source: A. Turer)

Fig. 14. Failure of unrestrained wall and failure of rounded roof beam (Erzurum, 2004) (Source: A. Turer).

In Fig. 15, several crack and failure types are summarized for masonry structures. Sequences of failure and occurrence of damage types suggest that the points which govern damage progression are:

1. Corners are more likely to fail than mid-wall elements.

2. Any panel between two corner failures is unrestrained and is unlikely to remain standing.

3. Non-load bearing panels are more likely to fail than load bearing.

4. Elements generally fail one after another.

5. The failure of one element increases the probability of failure of neighbouring elements (Yarar, 1985).

\subsection{Behaviour of stone masonry structures}

Stone masonry buildings, being an inherently rigid and brittle type of structures, does not exhibit a wide spectrum of modes and degrees of failure. It is poor when field rubble is used and bonded with mud mortar, without quoins and with no through stones. Researchers conducted have identified that in most traditional stone masonry construction, the floors or roofs span only one way, and entirely lack in-plane shear strength. Thus lack of structural integrity is the greatest source of weakness. Collapse of walls happens usually due to failure of connections between wall and wall, wall and roof and wall and foundations. Failure of the weak stone walls is followed by the falling of the heavy roof (Weldelibanos, 1993).

Failure or crack pattern of stone structures are different from brick, briquette or kerpic structures. Diagonal cracks are not formed. The reason of that is stone walls do not constitute a homogeneous and continuous structure. Failure is followed by disintegration of the walls.

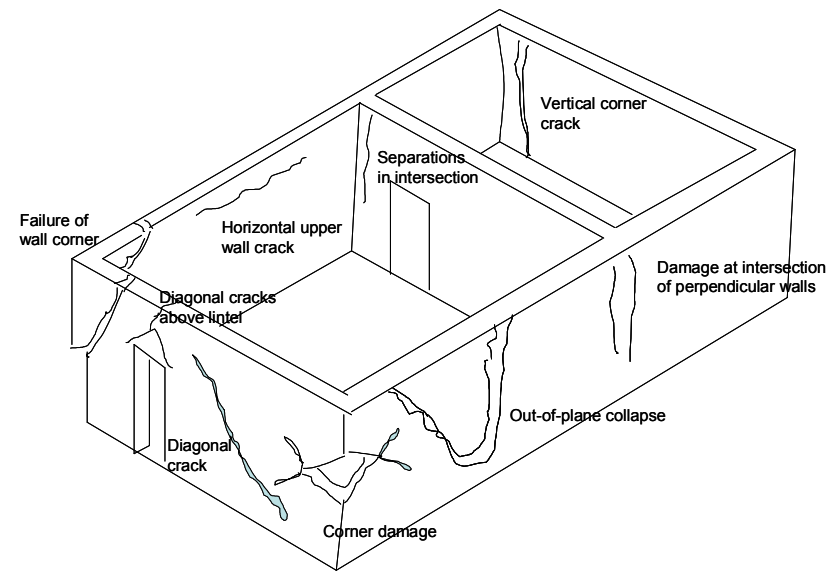

Fig. 15. Summary of typical damage and crack types.

In eastern of Anatolia, general structural type is stone masonry and especially random rubble debris stone is used and many structures incorporated timber reinforcement and had timber roofs. Those stones are collected from river basins and have round shapes. Sometimes the surface is covered with moss. As a mortar, mud is commonly used. After the mud shrunk, the only force that can withstand shear forces is the friction between stone blocks. The general roof type is flat earth roof. Construction of stone buildings is easy because they do not require formwork or reinforcement workmanship. On the other hand, wall thicknesses of such building are very thick. Especially on the east part of Turkey, due to temperature differences between day and night, walls may be $50-70 \mathrm{~cm}$, which creates high seismic forces. It is known that the thickness of the earth layer over the roof can reach up to $50 \mathrm{~cm}$ causing excessive loading on the structure. The dead weight of the earth roof can be $0.75-1.0 \mathrm{t} / \mathrm{m}^{2}$. Snow accumulated on the roof during winter times is stripped off. 

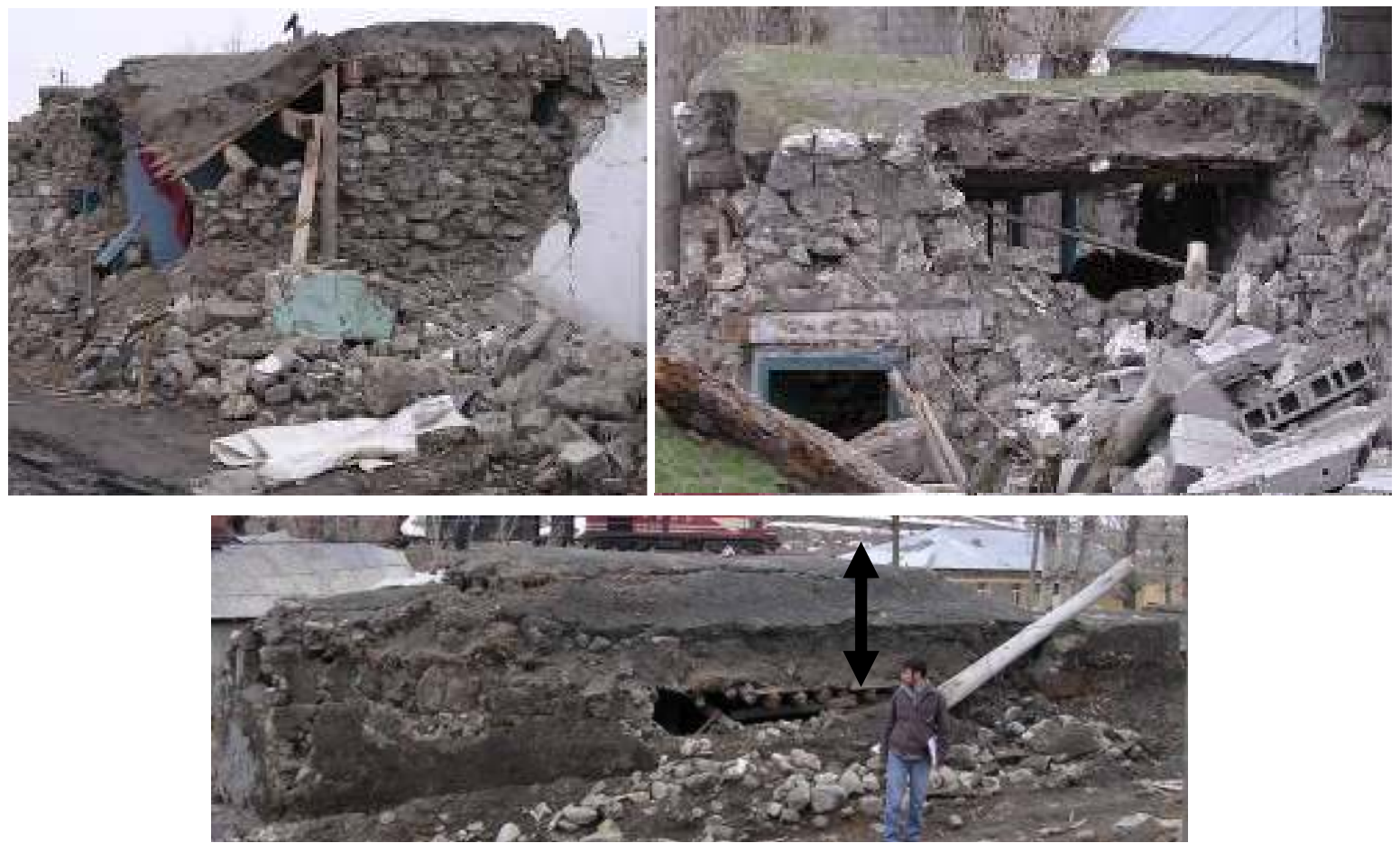

Fig. 16. Heavy roof of Eastern Anatolia houses (Erzurum, 2004) (Source: A. Turer).

The sagging created on the earth roof by the additional snow load is filled with fresh soil in springtime and it is compacted with the use of a heavy stone cylinder named 'log' which results in the periodical increase in soil depth over the roof increasing the load applied on the walls too (Fig. 16). Additionally, wooden roof beams can decay due to organic attack and moisture and as a result they deteriorate. This creates displacement of roof beams and earth roof. Sagged portion of the roof is filled again with soil and compacted. This load is added to most critical section of the beam.

With just a few exceptions all the different rural structural types used a timber joist system of varying degrees of complexity to support the soil roof covering. The load carrying timber most widely used in the roof was KavakPoplar (Fig. 17). In some stone and earthen (kerpic) structures, wooden roof beams are supported by vertical wooden logs. In all but the newest of structures beams and columns were round or sub-round in section. This column logs can be placed within the wall or out of the walls but in the rooms (Fig. 18). The connections of column logs with roof beams are not adequate. The beams were supported on columns which were flat topped or in a few cases hollowed out to form a saddle bearing surface. In no cases were rigid fixing mechanisms between columns and beams observed. The trunks are generally without its bark. This made connections and good bearing surfaces between them virtually impossible, for example, where two horizontal beams cross at right angles and one of them simply rests upon the other. Round sectional beams were prone to roll off the other during the earthquake induced motions. Also, the round beam-ends point loaded (to an excessive degree) the supporting walls beneath (Hughes, 2000). Also there is no diagonal bracing exist. The lateral drift of the frame is limited if there exist masonry wall in between frame bays. If the column logs are located out of the wall, as shown in Fig. 18b, lateral rigidity of the frame is low.

The roof beams are generally round in section. Rounded beams can easily roll over the vertical logs. Round or the more recent square section beams sat on the wall plate the bearing lengths were nearly always too short, for example, about $100 \mathrm{~mm}$. This is also the case where the beams were embedded into the wall and in a wall $700 \mathrm{~mm}$ wide the beam bearings were often no more than $200 \mathrm{~mm}$. In these structures, out-of-plane failure of stone or earthen roofs, failure of wooden frame and total failure of the structures are probable.

A different type of failure in masonry structures can be observed in random rubble stone masonry structures. This type can be considered as an example of poor quality of stone masonry, which has abundantly encountered in many villages of Turkey. Earthquake behaviour of random rubble stone masonry is the worst one among the rural structure types. Since the walls of masonry structures are quite thick in general and formed by fragmented material, the expected damage is moderate. As a result of thicker walls and absence of transverse connection stones, independent behaviour of double skinned bearing walls, that is, vertical separation of 
internal and external surfaces (Fig. 19) the walls cannot act as one single unit and this lead to failure of outer skin outwards due to plate action. The reason for that is, inner and outer skins do not have enough transverse connection "through" or "bond stones" and weak mortar filling between the skins. In half-dressed stone masonry, the surface stones are pyramidal in shape having more or less an edge contact one over the other, thus the stones have an unstable equilibrium and easily disturbed under shaking condition.

Block-stone walls possess better structural properties compared with those of random rubble debris stone. The shape and dimensions of the stones are important for lateral load carrying capacity point of view. Whatever the mortar type is, stone blocks having bigger dimensions than the wall thickness, can not be joined to each other with mortar (Fig. 20).

\subsection{Behaviour of earthen (kerpic) structures}

Traditional adobe construction responds very poorly to earthquake vibrations. Earthen (kerpic) houses respond to lateral loads with wide cracks in walls, separation of walls at corners, and complete collapse of heavy mass of debris, walls, roofs and floors causing a significant loss of life of residents and property. Most common causes of failure and modes of failure are; due to bending and overturning of walls, the great height and large unsupported length of wall, great mass of roof or walls, poor connections between intersecting walls or between roof and walls (Weldelibanos, 1993). Seismic deficiencies of kerpic construction are caused by the heavy weight of the structures (due to heavy earthen roof (Fig. 21) and thick walls), their low strength, and brittle behaviour. During strong earthquakes, due to their heavy weight, these structures develop high levels of seismic forces they are unable to resist, and therefore they fail abruptly (Blondet et al., 2003).

Earthquake resistance of kerpic structures is better than that of random rubble stone structures. In kerpic structures, the mud mortar, when dried, form a continuous and homogeneous medium with adobe blocks. While in mud mortar-rubble masonry there is no binding between individual stones, only the friction between the stones resists earthquake forces.

Kerpic structures are common in middle Anatolia of Turkey where there is no forests and big stone quarries. Afyon and Aksehir were affected during Sultandagi earthquake. In the rural part of these towns, the general construction types are kerpic, himis or Baghdadi. Although recently reinforced concrete is used (Fig. 22), kerpic is still being used (Fig. 2). The structures near Aksehir are constructed with earthen blocks without any hatil (Fig. 23). Most of them have two storeys and damaged or collapsed during the earthquake. The above explained damage and failure characteristics of masonry structures are observed after the earthquake. In some kerpic structures, first story is masonry kerpic and wooden frame is used for the second storey. Again connec-

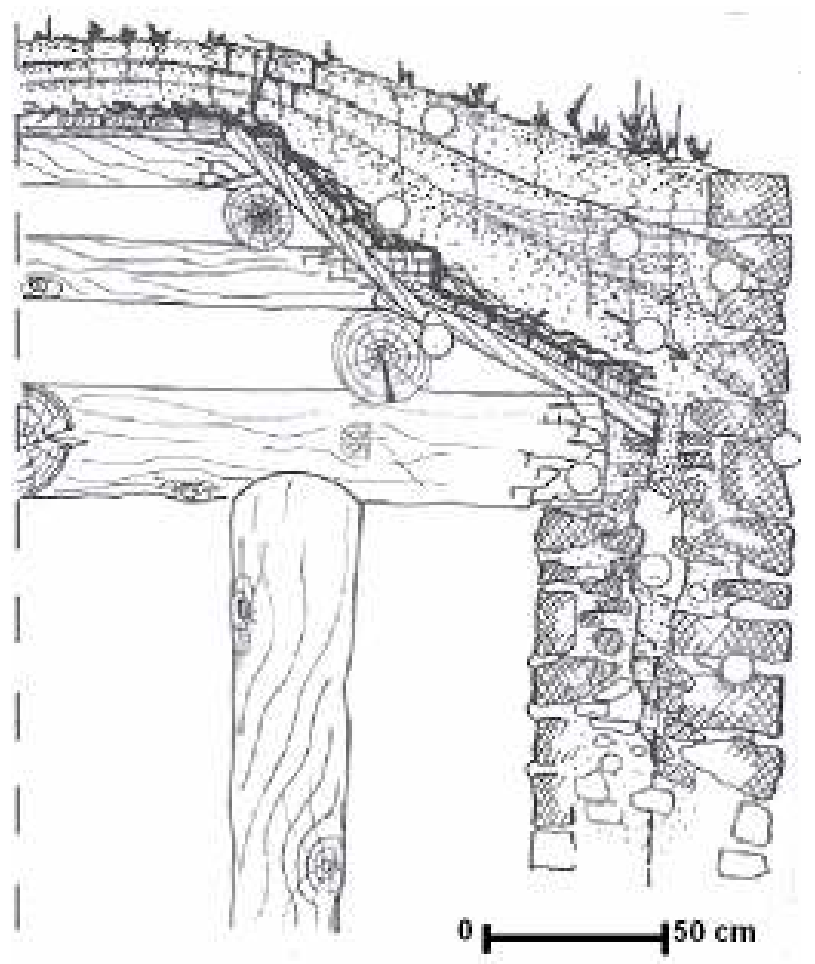

Fig. 17. Wooden frame of stone building in eastern Anatolia (Hughes, 2000).

tions between wooden beams and vertical frame elements are inadequate. Out-of-plane failures of earthen infill walls were observed frequently (Fig. 24).

\subsection{Wooden framed structures (Himis and Baghdadi)}

The seismic performance of this type of structures is given Doaangün's (2007) study with many details. Briefly, Himis structures have better seismic properties compared with masonry structures. They can be considered as more ductile and have more capabilities to dissipate earthquake energy. The main skeleton of the structure is composed of wooden frames with diagonal bracings. The subdivision of each structural bay with a tight network of vertical, horizontal, and diagonal timbers, rather than vertical studs alone, appeared to have been successful in reducing the possibility of the masonry falling out of the frames. The closely spaced studs reduced the likelihood of the propagation of $X$ shear cracks within any single panel which is so common in the infill in the modern reinforced concrete buildings. The connections of roof, floors, vertical framing elements and bracing elements make the building a single solid structure unit and are important features for holding a building together during earthquakes. Due to existence of studs, the loss of portions or all of several panels did not appear to lead progressively to the destruction of the rest of the wall. 

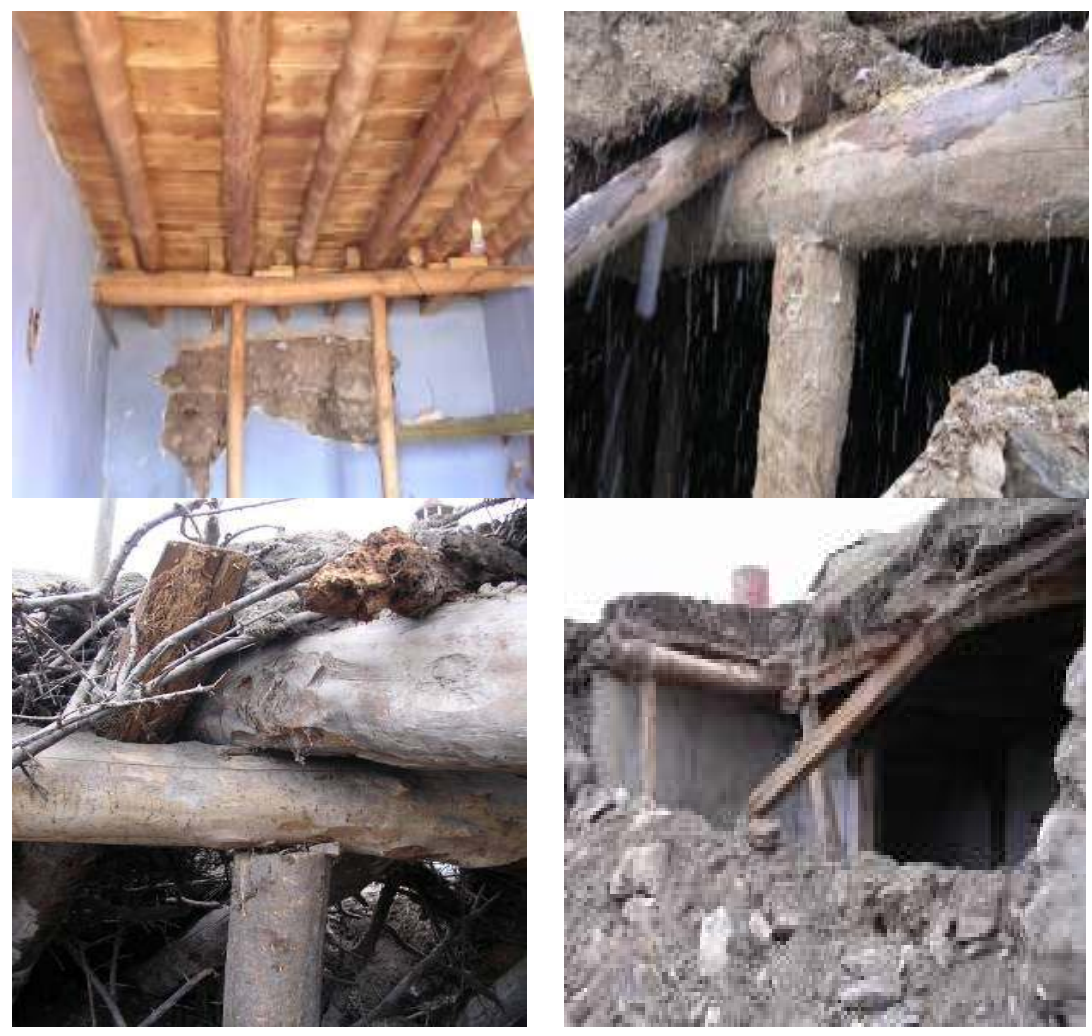

Fig. 18. Wooden frames, connection of them and failure observed in east Anatolia (Source: A. Turer).
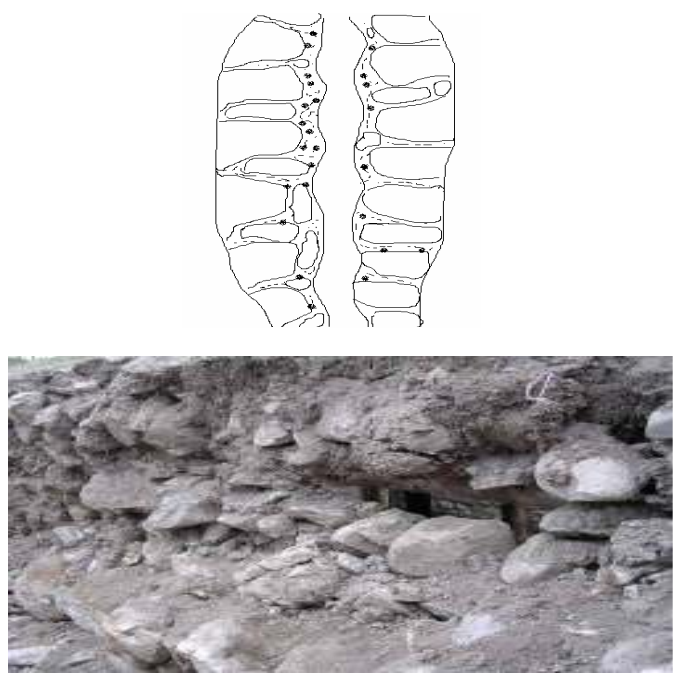

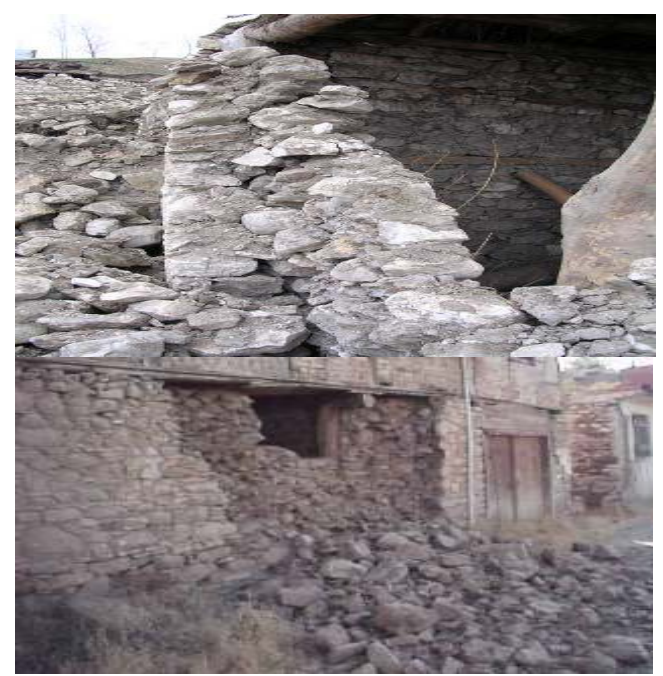

Fig. 19. Wall delaminated with buckled skins (Source: T. Wasti).

The typical himis construction does not have mechanical ties between the timber and masonry to hold the infill masonry in place. As a result, in some cases, small sections of the infill were shaken out from between the studs near the top of the upper walls. The observed performance of himis buildings suggest, that due the lack of rigid diaphragm action, most of the walls responded individually during the seismic attack. Moreover as a consequence of weak connections between the perimeter and orthogonal partitioning walls, separation occurred and most of the walls collapsed in the out of plane direction (Fig. 25). 

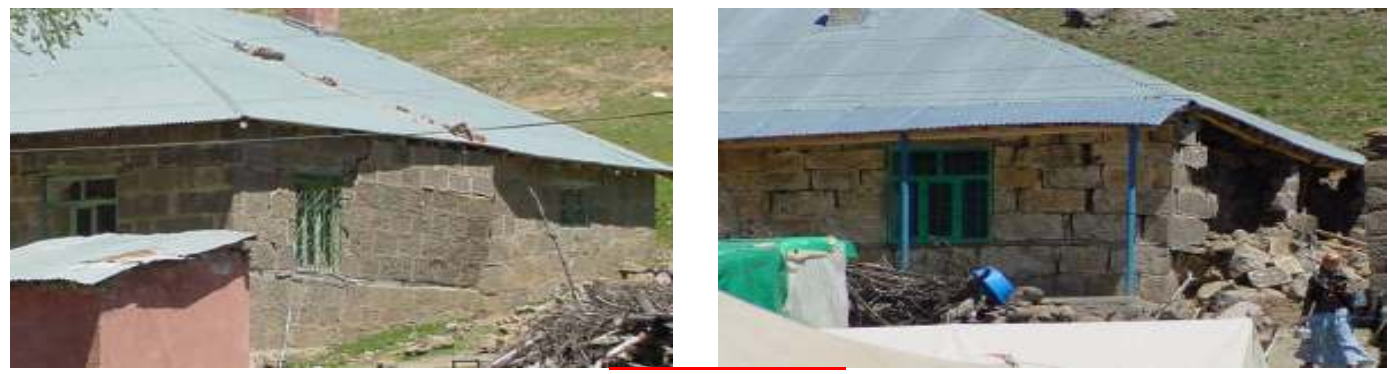

Fig. 20. Failure of block stone masonry houses (Source: A. Turer).
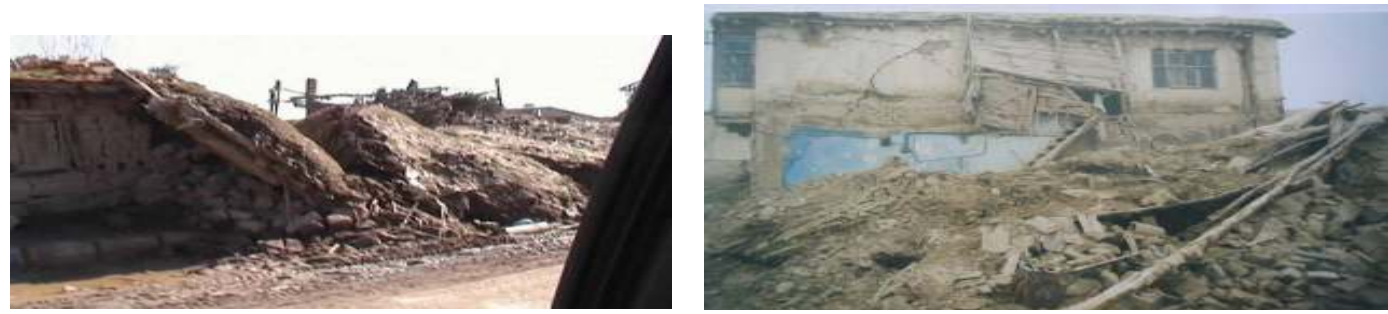

Fig. 21. Failure of heavy roof of kerpic houses (Sultandagi Earthquake) (Source: D. Aydin).

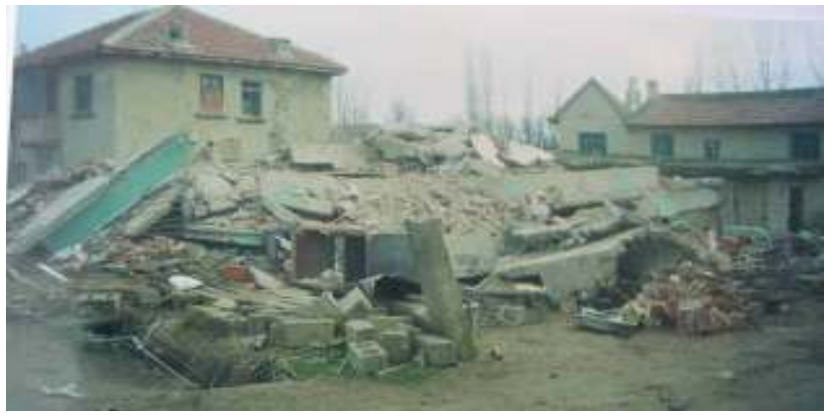

Fig. 22. Collapsed reinforced concrete building after Sultandagi earthquake (Source: H. H. Korkmaz, S. Z. Korkmaz, M. S. Donduren).

Bagdadhi type generally lighter and the numerous wooden lathes nailed on the framing provide considerably high damping and energy absorption to the structure. These types of structures are also more ductile than himis structures (Tobriner, 2000).

\section{Conclusions}

It is designated that $91 \%$ of the national territory and $98 \%$ of the overall population of Turkey are encompassed by the earthquake regions. The population of people living in rural districts or villages has increased approximately $4 \%$. Additionally, vast majority of the people especially those immigrating the city from rural districts inhabits buildings constructed with their own efforts like shanties without any en-

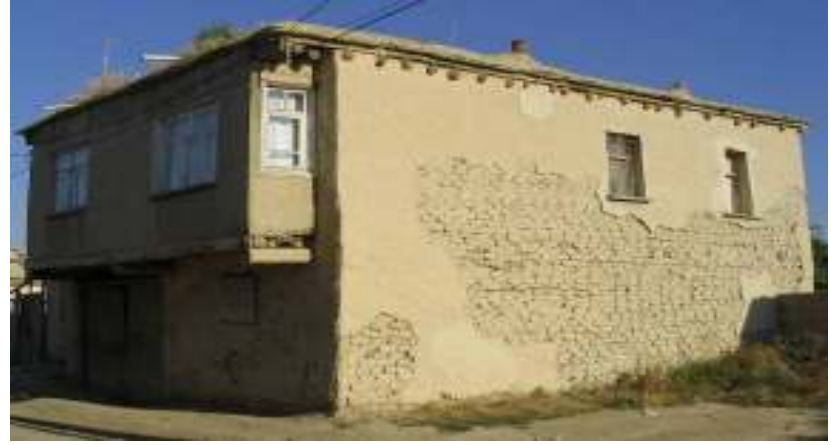

Fig. 23. A kerpic structure in Aksehir with two storeys and absence of hatil (Source: H. H. Korkmaz, S. Z. Korkmaz, M. S. Donduren).

gineering service. In Istanbul which is located 1st earthquake zone, $60 \%$ of the residences are squatter houses.

The following are the main weakness in the materials and unreinforced masonry constructions and other reasons for the extensive damage of masonry buildings.

- Very low tensile and shear strength particularly with poor mortar.

- Brittle behaviour in tension as well as compression.

- Stress concentration at corners of windows and doors.

- Overall unsymmetry in plan and elevation of building.

- Unsymmetry due to imbalance in the sizes and positions of walls and openings in the walls. 

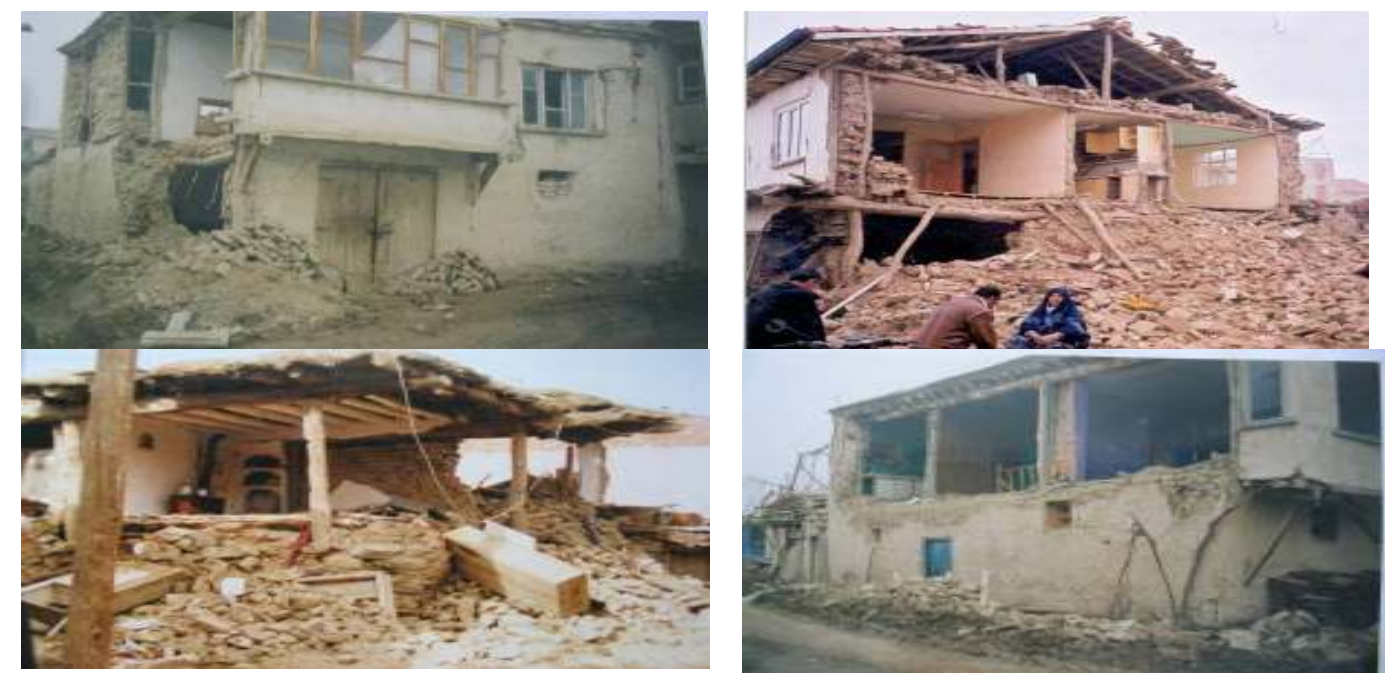

Fig. 24. Out-of-plane failure of masonry walls (Source: D. Aydin).
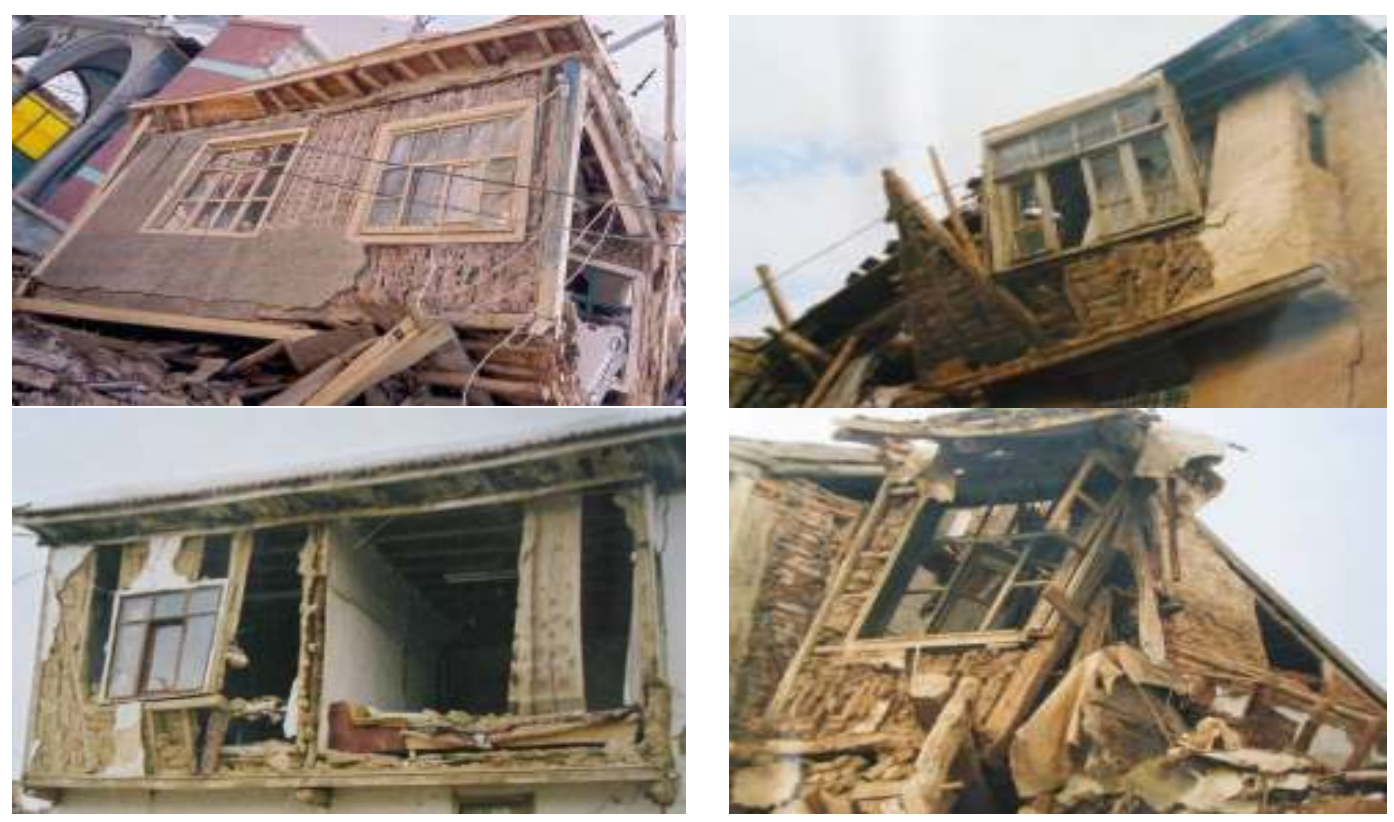

Fig. 25. Failure and damage of himis buildings (Source: D. Aydin).

- Defects in construction such as use of substandard materials, unfilled joints between bricks, not-plump walls, improper bonding between walls at right angles etc.

After recent earthquakes, in rural areas of Turkey, following deficiencies are observed leading to failure of nonengineered structures.

- Heavy earthen roof weight and very stiff buildings attracting large seismic inertia forces.

- Absence of horizontal girders-hatil in masonry structures.

- Use of random rubble stone masonry as construction material for structures.

- Use of block stones with larger dimension than wall thickness.

- Lack of transverse connecting stones within the walls.

- Weak connection between wall and wall, roof and wall.

- Improper bonding between walls at right angles. 
- Use of rounded logs as roof beams.

- Very poor or absence of connection mechanism for wooden framed masonry houses.

- Construction of multi-storey kerpic houses.

- Hammering affect between adjacent rural structures.

- Construction of flexible roof systems which result in deficiencies in box behaviour of masonry houses.

Earthquake resistant construction of rural dwelling is well known. But further studies about new techniques to improve earthquake behaviour of existing rural structures are needed. Those methods must be simple and economic such that owner of the house can manage to apply it.

Rules of earthquake resistant design must be presented to the home owners who construct his house by himself and construction labor of rural areas. At this point education is very important. Continuous seminars, courses are needed. Also brochures and handout must be prepared and distributed to the villages and towns.

Edited by: M. E. Contadakis

Reviewed by: two anonymous referees

\section{References}

Dogangun, A. : Performance of reinforced concrete buildings during the May 1, 2003 Bingöl Earthquake in Turkey, Engineering Structures, 26, 841-856, 2004.

Kaltakci, M. Y., Arslan, M. H., Korkmaz, H. H., and Ozturk, M.: An investigation on failed or damaged reinforced concrete structures under their own-weight in Turkey, Engineering Failure Analysis, 14(6), 962-969,2007.

Arslan, M. H. and Korkmaz, H. H.: What is to be learned from damage and failure of reinforced concrete structures during recent earthquakes in Turkey?, Engineering Failure Analysis, 14(1), 122, 2007.

Elnashai, A. S.: Analysis of the damage potential of the Kocaeli (Turkey) earthquake of 17 August 1999, Engineering Structures, 22, 746-754, 2000.

Kaplan, H., Yilmaz, S., Binici, H., Yazar, E., Cetinkaya, N.: May 1, 2003 Turkey-Bingol earthquake: damage in reinforced concrete structures, Engineering Failure Analysis, 11, 279-291, 2005.

Cagatay, I.: Experimental evaluation of buildings damaged in recent earthquakes in Turkey, Engineering Failure Analysis, 12, 440$452,2005$.

Scawthorn, C. and Johnson, G. S.: Preliminary report Kocaeli (Izmit) earthquake of 17 August 1999, Engineering Structures, 22, 727-745, 2000.

Adalier, K. and Aydingun, O.: Structural engineering aspects of the June, 1998 Adana-Ceyhan (Turkey) Earthquake, Engineering Structures, 23, 343-355, 2001.

Sezen, H., Whittaker, A. S., Elwood, K. J., and Mosalam, K. W.: Performance of reinforced concrete buildings during the August 17, 1999 Kocaeli, Turkey Earthquake and the seismic design and construction practice in Turkey, Engineering Structures, 25, 103 $114,2003$.
Bruneau, M.: Building Damage from the Marmara, Turkey Earthquake of August, 1999, J. Seismology, 6, 357-377, 2002.

Ahmadizadeh, M. and Shakib, H.: On the December 26, 2003, southeastern Iran earthquake in Bam region, Engineering Structures, 26, 1055-1070, 2004.

Hughes, R.: Hatl construction in Turkey, International conference on the seismic performance of traditional buildings, Istanbul, Turkey, 1-9, 2000.

Catal, H. H.: A report October on Dinar 1995, and earthquake response spectra, Engineering Structures, 19(7), 594-602, 1997.

Arslan, M. H., Korkmaz, H. H., and Gulay, F. G.: Damage and failure pattern of prefabricated structures after major earthquakes in Turkey and shortfalls of the Turkish Earthquake code, Engineering Failure Analysis, 13(4), 537-557, 2006.

Ulusay, R., Aydan, O., Erken, A., Tuncay, E., Kumsar, H., and Kaya Z.: An overview of geotechnical aspects of the Cay-Eber (Turkey) earthquake, Engineering Geology, 73, 51-70, 2004.

Ulusay R. and Aydan O.: Characteristics and geo-engineering aspects of the 2003 Bing"ol (Turkey) earthquake, J. Geodynam., 40, 334-346, 2005

Sancio, R. B., Bray, J. D., Stewart, J. P., Youd, T. L., Durgunoglu, H. T., Onalp, A., Seed, R. B., Christensen, C., Baturay, M. B., and Karadaylar, T.: Correlation between ground failure and soil conditions in Adapazari, Turkey, Soil Dynamics and Earthquake Engineering, 22, 1093-1102, 2002.

Bayraktar, A., Coskun, N., and Yalcin A.: Damages of masonry buildings during the July 2, 2004 Dogubayazit (Agr,) earthquake in Turkey, Engineering Failure Analysis, 14, 147-157, 2007.

Erdik, M., Demircioglu, M., Sesetyan, K., Durukal, E., and Siyahi, B.: Earthquake hazard in Marmara Region, Turkey, Soil Dynamics and Earthquake Engineering, 24, 605-631, 2004

Binici H. : March 12 and June 6, 2005 Bingol-Karliova earthquakes and the damages caused by the material quality and low workmanship in the recent earthquakes, Engineering Failure Analysis, 14, 233-238, 2007.

Guchan, N. S.: Observations on earthquake resistance of traditional timber-framed houses in Turkey, Building and Environment, 42, 840-851, 2007.

Inel M., Ozmen H. B., and Bilgin, H.: Re-evaluation of building damage during recent earthquakes in Turkey, Engineering Structures, 30, 412-427, 2008.

Pamuk, A., Kalkan, E., and Linga, H. I.: Structural and geotechnical impacts of surface rupture on highway structures during recent earthquakes in Turkey, Soil Dynamics and Earthquake Engineering, 25, 581-589, 2005.

Korkmaz, K. A.: Seismic safety assessment of unreinforced masonry low-rise buildings in Pakistan and its neighbourhood, Nat. Hazards Earth Syst. Sci., 9, 1021-1031, 2009, http://www.nat-hazards-earth-syst-sci.net/9/1021/2009/.

Kaplan, H., Yilmaz, S., Akyol, E., Sen, G., Tama, Y. S., Cetinkaya, N., Nohutcu, H., Binici, H., Atimtay, E., and Sarisin, A.: 29 October 2007, Çameli earthquake and structural damages at unreinforced masonry buildings, Nat. Hazards Earth Syst. Sci., 8, 919-926, 2008, http://www.nat-hazards-earth-syst-sci.net/8/919/2008/.

Ersubasi, F.: Evaluation of different strengthening techniques for masonry structures and testing dynamic properties in a shaking table facility. MSc Thesis, Selcuk University Graduate School of Natural and Applied Sciences, Konya-Turkey, 2008. 
Korkmaz, S. Z.: Seismic improvement of rural houses, Phd Thesis, Selcuk University Graduate School of Natural and Applied Sciences, Konya-Turkey, 2007.

Weldelibanos, F. A.: Survey of earthquake mitigation strategies \& building principles for small traditional dwellings, McGill University, Master of Architecture Thesis, Montreal. 1993.

Shaw, R. and Okazaki, K.: Guidelines for earthquake resistant design, construction, and retrofitting of buildings in Afghanistan, Ministry of Uurban Development and Housing (MUDH), Government Of Afghanistan United Nations Centre For Regional Development (UNCRD) Disaster Management Planning Hyogo Office, 2003.

Ginell, W. S. and Tolles, E. L.: Seismic stabilization of historic adobe structures, Journal of the American Institute for Conservation, 39(1), 147-163, 2000.

Erbay, O.: A methodology to assess seismic risk for populations of un-reinforced masonry buildings, $\mathrm{PhD}$ Thesis, University of Illinois at Urbana-Champaign, 2004.

Coburn, A.: Analysis of earthquake damage and proposals for strengthening stone masonry Buildings in Eastern Anatolia, Middle East and Mediterranean Regional Conference on Earthen and Low-Strength Masonry Buildings in Seismic Areas, Ankara, Turkey, 445-470, 1986.
Yarar, R.: Earthquake behaviour of rural buildings in Turkey,. Seminar on Contemporary Rural Housing in Seismic Areas, Istanbul Turkey, 1985.

Patel, D. B. and Pindoria, K.: Repair and strengthening guide for earthquake damaged low rise domestic buildings in Gujarat, India GREAT Publication, 2001.

Blondet, M., Garcia, G. V., and Brzev, S.: Earthquake-Resistant Construction of Adobe Buildings: A Tutorial, Published as a contribution to the EERI/IAEE World Housing Encyclopedia, www.world-housing.net, 2003.

Dogangun, A., Tuluk, O. I., Livaoglu, R., and Acar, R.: Traditional wooden buildings and their damages during earthquakes in Turkey, Engineering Failure Analysis, 13(6), 599-608, 2007.

Tobriner, S.: Wooden architecture and earthquakes in Turkey: a reconnaissance report and commentary on the performance of wooden structures in the Turkish earthquakes of 17 August and 12 November 1999. In: International conference on the seismic performance of traditional buildings, Istanbul, Turkey, 16-18, 2000 . 